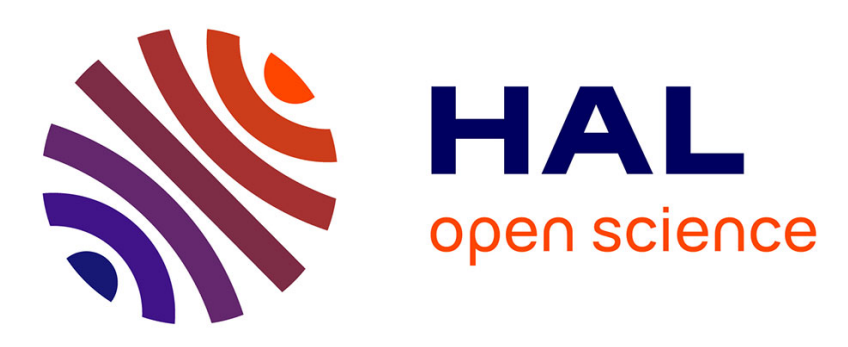

\title{
Radon Activity in Volcanic Gases of Mt. Etna by Passive Dosimetry
}

Luca Terray, Pierre-jean Gauthier, Vincent Breton, Salvatore Giammanco, Olgeir Sigmarsson, Giuseppe Salerno, Tommaso Caltabiano, Alain Falvard

\section{- To cite this version:}

Luca Terray, Pierre-jean Gauthier, Vincent Breton, Salvatore Giammanco, Olgeir Sigmarsson, et al.. Radon Activity in Volcanic Gases of Mt. Etna by Passive Dosimetry. Journal of Geophysical Research : Solid Earth, 2020, 125 (9), pp.e2019JB019149. 10.1029/2019jb019149 . hal-02944147

\section{HAL Id: hal-02944147 \\ https://hal.uca.fr/hal-02944147}

Submitted on 19 Nov 2020

HAL is a multi-disciplinary open access archive for the deposit and dissemination of scientific research documents, whether they are published or not. The documents may come from teaching and research institutions in France or abroad, or from public or private research centers.
L'archive ouverte pluridisciplinaire HAL, est destinée au dépôt et à la diffusion de documents scientifiques de niveau recherche, publiés ou non, émanant des établissements d'enseignement et de recherche français ou étrangers, des laboratoires publics ou privés. 
${ }^{1}$ Laboratoire Magmas et Volcans, Université Clermont Auvergne, Aubière, France

$5 \quad{ }^{2}$ Laboratoire de Physique de Clermont, Université Clermont Auvergne, Aubière, France

$6{ }^{3}$ Istituto Nazionale di Geofisica e Vulcanologia, Osservatorio Etneo, Catania, Italy

7

8

9

10 


\section{Abstract}

Radon $\left({ }^{222} \mathrm{Rn}\right)$ activity in air was measured for about six months at the summit of Mt. Etna Central Crater (Sicily) by integrative radon dosimetry at two different heights above ground level ( $5 \mathrm{~cm}$ and 1 m). This technique for air radon monitoring proved operational in the harsh volcanic environment of Mt. Etna summit with a $94 \%$ recovery rate of dosimeters. In the South-East sector exposed to the main gas plume, mean radon activity in free air (height $1 \mathrm{~m}$ ) is significantly higher than the local background and the ground level activity (height $5 \mathrm{~cm}$ ). The results strongly suggest that the plume is enriched in radon by $\approx 550 \mathrm{~Bq} / \mathrm{m}^{3}$, which has never been evidenced before. Radon activities also reflect soil degassing occurring in the proximity of the crater, with increased ground level activities in zones of enhanced soil fracturing and degassing. Radon measurements also revealed a hotspot in front of the Voragine vent with extraordinary high levels of air activities $\left(26 \mathrm{kBq} / \mathrm{m}^{3}\right.$ at ground level and $8 \mathrm{kBq} / \mathrm{m}^{3}$ in free air). The temporal variation of radon activity was investigated by replacing a few stations half way through the exposure period. The only significant increase was associated with the site located under the main gas plume and correlated with eruptive unrest within the crater. Finally, air radon levels higher than the recommended threshold of $300 \mathrm{~Bq} / \mathrm{m}^{3}$ were detected in several zones on the rim and could generate a non-negligible radiologic dose for workers on the volcano. 


\section{1) Introduction}

[1] Radon $\left({ }^{222} \mathrm{Rn}\right)$ is a radioactive noble gas produced by the decay of ${ }^{226} \mathrm{Ra}$. As such, radon abundance is generally high in U-bearing geological formations, including volcanic and geothermal zones (e.g., Monnin, 2001). Since the pioneering work of Chirkov at Karymsky volcano, Kamchatka (Chirkov, 1975), radon measurements at active volcanoes, either in fumaroles or in soil gases, have been carried out worldwide in order to investigate radon activity variations as a precursory monitoring tool (see recent reviews by Cigolini et al., 2016 and Morales-Simfors et al., 2020, and references therein). Albeit promising, the radon signature in soil gases and/or fumarolic discharges appears however not always easy to decipher. Besides the well-known diurnal and seasonal variation of radon emissions related to meteorological effects and earth tides, radon activities can indeed be affected by local variations of soil temperature and humidity, local stress regime constraints and other parameters which may hide the signature of magmatic processes at depth (Zimmer and Erzinger, 2003; Cigolini et al., 2016; Mollo et al., 2018).

[2] The primary magmatic vapor released in gaseous plumes at open-conduit degassing volcanoes thus could be an ideal candidate to investigate radon anomalies directly linked to magmatic processes at depth. Unfortunately, almost no systematic survey of in-air radon activities in volcanic plumes have been carried out so far, apart from a single study on short-lived ${ }^{222} \mathrm{Rn}$ daughters at Mount Erebus, Antarctica (Polian and Lambert, 1979). In marked contrast, emissions of the last three radon daughters (namely ${ }^{210} \mathrm{~Pb},{ }^{210} \mathrm{Bi}$ and ${ }^{210} \mathrm{Po}$ ) in volcanic plumes have been well established for more than 40 years (e.g., Lambert et al., 1976). The study of ${ }^{210} \mathrm{~Pb}^{210} \mathrm{Bi}^{210} \mathrm{Po}$ radioactive disequilibria in magmatic gases 
has proved efficient to infer degassing dynamics of active volcanic systems, either in a state of openconduit persistent degassing (Lambert et al., 1985; Gauthier et al., 2000; Le Cloarec and Pennisi, 2001; Allard et al., 2016), in an eruptive dome setting (Le Cloarec and Gauthier, 2003) or during lateral fissure eruptions (Gauthier et al., 2016).

[3] Early experiments by Sato et al. (1980) suggested that radon is thoroughly degassed from liquid silicates at magmatic temperatures, a finding later confirmed by radon analyses of freshly erupted lavas (Gill et al., 1985). However, an experimental investigation of radon diffusion in andesitic melts (Gauthier et al., 1999) suggested that complete radon degassing is achieved only when major gas species (mostly $\mathrm{CO}_{2}$ and $\mathrm{H}_{2} \mathrm{O}$ ) act as a radon carrier. Indirect evidence of sustained radon degassing from erupting magmas can be found in the observation of large ${ }^{210} \mathrm{~Pb}$ deficits over ${ }^{226} \mathrm{Ra}$ in some recent lavas (e.g., Gauthier and Condomines, 1999; Berlo et al., 2006). Meanwhile, ${ }^{210} \mathrm{~Pb}$ excesses over ${ }^{226} \mathrm{Ra}$ have been observed elsewhere suggesting the reverse behavior, that is radon accumulation at depth followed by its subsequent radioactive decay within the magma (e.g., Berlo et al., 2006; Condomines et al., 2010; Sigmarsson et al., 2015). The question whether radon is efficiently released through outgassing of magmatic volatiles at volcanic craters or decays out at depth, due to its relatively short half-life of 3.8 days, remains largely unanswered because magmatic plume emissions of radon have not yet been documented.

[4] In May 2018, we installed a network of radon passive dosimeters all around the rim of Mt. Etna Central Crater, in Sicily. The dosimeters were left on site for about five months (from May 24, 2018 to October 11, 2018), until their retrieval for the laboratory determination of radon activity. The first goal 
of the study was to determine mean radon levels in the air around the crater in order to constrain radon emissions related to volcanic plume, fumaroles, high soil degassing, or a combination of these various sources. The second goal of the study was to test the capability of radon measurements in air to be part of the monitoring system of active volcanoes, Mt. Etna being one of the best monitored volcano laboratory in the world (Bonaccorso et al., 2004). Finally, this study was also aimed at assessing the potential radiologic hazard associated to high radon levels in air around the crater, since Mt. Etna summit is systematically visited every year by thousands of tourists, scientists and volcanological guides, and health hazards related to volcanic gas plumes are often pointed out (Delmelle et al., 2002; Hansell and Oppenheimer, 2004).

\section{2) Area of study}

[5] Mt. Etna is a stratovolcano located on the east coast of Sicily and one of the most active volcanoes in Europe. Its edifice is a $3300 \mathrm{~m}$ above sea level (a.s.l.) high cone with a collapsed eastern flank (Valle del Bove) and a complex summit morphology (e.g., Neri et al., 2017) composed of three different groups of active craters (see Figures 1 and 2): (i) the Central Crater (CC) hosting two inner craters named Bocca Nuova (BN) and Voragine (VOR), (ii) the North-East Crater (NEC), and (iii) the South-East Craters. Its present eruptive activity is characterized by diverse eruptive styles, from purely effusive to mild and violent strombolian with very energetic lava fountains (e.g., Allard et al., 2016). In addition, Mt. Etna is often classified as an open-conduit volcano because of the continuous emission of large quantities of magmatic gases from its main craters (Aiuppa et al., 2008; Salerno et al., 2009a). An active hydrothermal system is also located at shallow depth beneath its summit (Liotta et al., 2010). 
[6] This study focused on the Central Crater because persistent passive or active plume emissions from

Bocca Nuova and Voragine vents ensured an almost continuous presence of magmatic gases on the crater rim, whereas other craters were mostly emitting gas through fumarole fields. The degassing regime of the Central Crater between May and October 2018 reflects the recent eruptive activity:

- (i) BN and VOR craters merged after the December 2015 and May 2016 paroxysmal eruptions and eruptive products totally filled the two craters (Corsaro et al., 2017; Marchese et al., 2018). Subsequently, the tectonic structure of the summit was considerably modified and a swarm of NorthSouth oriented fractures opened from the North-East Crater to the South-East Craters, passing east of the Central Crater (Fig. 1a; see also Marchese et al., 2018). It led to both enhanced fumarolic activity and increased diffuse soil degassing within the Central Crater and around it (see for instance Figure 3 in Marchese et al., 2018). Our field observations suggest that this degassing activity was still present, albeit at lower intensity, in 2018 at the time of the study.

- (ii) Since May 2016, BN and VOR craters have been subsiding, progressively reforming the former geometry of the Central Crater. In August 2016, a degassing pit opened on the inner east flank of VOR crater twenty meters below the rim (Marchese et al., 2018; VOR vent, see Figures 1 and 2), apparently draining most of diffuse emissions nearby and remained active in 2018 at the time of our measurements. In early 2018, a new degassing pit opened on the west side of BN crater floor (BN1, see Figures 1 and 2), where most of the degassing activity took place.

- (iii) In late May/early June 2018, at the start of the experiment, activity mostly consisted in sustained degassing from the BN1 vent, and additional mild degassing at the NE Crater (Figure 2). In the course 
of summer 2018, a slight unrest occurred in the eruptive activity as witnessed by thermal anomalies

119 observed from the Sentinel imager satellite (Figure 2) and other remote sensing approaches (Marchese et al., 2019), as well as an increase in $\mathrm{SO}_{2}$ fluxes (see Supplementary Material) and volcanic tremor (e.g., Bollettino settimanale sul monitoraggio vulcanico, geochimico e sismico del vulcano Etna, 20/08/2018 - 26/08/2018, 2018). Magmatic explosions were further reported by witnesses at BN

123 (explosion bangs and visual observations of volcanic bombs ejected from the craters), this unrest period culminating in the opening of a new vent on the east side of the BN crater (BN2, see Figures 1 and 2) in August 2018 (see Figure 4 in Marchese et al., 2019).

126 [7] Beside the activity at Central Crater, major eruptive events during the 2016-2018 period included

127 a sequence of six effusive eruptions at South East Craters in February-March 2017 (De Beni et al., 128 2019), a short strombolian and effusive episode at New South East Crater by late August 2018 and a 129 lateral fissure eruption in December 2018 (De Novellis et al., 2019).

\section{3) Methods}

[8] A temporary network of radon passive dosimeters was deployed for five months (from May to

132 October 2018) around the Central Crater of Etna and in the close vicinity of the summit area in order to assess radon levels at Mt. Etna summit. The network initially consisted in 29 monitoring stations set on the Central Crater rim (yellow and purple dots in Figure 1a) and 3 reference stations at distance

135 from the summit area (La Montagnola, Pizzi Deneri, Torre del Filosofo, Fig. 1b). An example of radon

136 station is shown in Figure 3. It consists of two dosimeters (one at ground level - i.e., $5 \mathrm{~cm}$ above ground

137 - and one in free air - i.e., at $1 \mathrm{~m}$ elevation) fixed to a $1.5 \mathrm{~m}$ high wooden stick solidly anchored to the 
139 from that of plume radon emissions. The bottom dosimeter would indeed mostly reveal the intensity of very local soil emissions while the top dosimeter will also be sensitive to radon from further distant

141 sources and transported by the wind (such as degassing vents). In July 2018, dosimeters at five

142 monitoring stations were picked up for analysis and immediately replaced by new dosimeters.

143 Additionally, a fourth reference station was installed further from the summit area, down in the Valle

144 del Bove (Fig 1b). As a whole, no less than 76 passive dosimeters were used for this experiment.

145 [9] For this experiment, we used DPR2 dosimeters provided by the Algade company (Bessines-sur-

146 Gartempe, France). These dosimeters are made of a LR-115 (cellulose nitrate) sensitive film,

147 encapsulated in a sealed plastic half-dome in order to prevent both thoron $\left({ }^{220} \mathrm{Rn}\right)$ and radioactive

148 aerosol particles from contributing to the measurement. The Algade company indicates a minimum

149 exposure period of two months (indoor conditions) in order to properly measure a radon activity of

150 about $20 \mathrm{~Bq} / \mathrm{m}^{3}$. Although LR-115 films had been previously used to measure in-soil radon activities on

151 volcanoes (e.g., Seidel and Monnin, 1984), they were used for the first time in outdoor conditions on

152 a volcano during the present study. It was thus decided to leave dosimeters in the field for the whole

153 summer period (May 24 - October 11) in order to ensure sufficient radon exposure. Nonetheless, five

154 crater stations were replaced on the $6^{\text {th }}$ of July 2018 with several objectives: (i) validate the

155 methodology by checking that cellulose nitrate films were not corroded by acid gases and damaged by

156 moisture, (ii) check the exposure level after two months in order to avoid film saturation and (iii) look

157 for potential temporal variations between May-July and July-October 2018. After collection of the 158 passive dosimeters in the field, they were sent to the Algade laboratory (within two days) where the 
details; e.g., Seidel and Monnin, 1984). Radon activities were obtained within two weeks, with a global

$2 \sigma$ uncertainty (counting statistics, calibration error, error due to temperature variations during the chemical processing of the dosimeter, error coming from the slightly variable quality of the sensitive films).

[10] Because passive dosimetry integrates radon activity in air over a long period of time (weeks to months), it filters out the large variability of radon activity in air due to short-period ( $<1$ day) fluctuations, often inherited from meteorological fluctuations (e.g. Zimmer and Erzinger, 2003). As such, it is an easy-to-deploy and low-cost technics allowing determination of a mean value representative of radon emission and accumulation at a given place over a given time period. Moreover, a dosimeter does neither require a power supply nor data logging system and it can be installed for several months even in harsh outdoor conditions without damage.

171 [11] In order to identify the zone under volcanic plume influence, wind direction and intensity over

172 the crater during the experiment period, May to October 2018, are needed. We used open-access data

173 acquired by radiosondes launched twice $a$ day at Trapani in western Sicily

174 (http://weather.uwyo.edu/upperair/sounding.html). Wind direction and horizontal wind speed were

175 obtained from each radiosonde profile, selecting the values measured in the range of elevation of Mt.

176 Etna summit craters (between 3000 and 3400 meters a.s.l.). Although radiosonde data refer to a site

177 located $220 \mathrm{~km}$ away from Mt. Etna, high-altitude winds are relatively stable over long distances, 
[12] Out of 76 installed dosimeters, only three were missing at the end of the experiment. All films but was clogged into a cm-thick crust of soldered dust and therefore excluded from the dataset as it was impossible to determine if radon could still enter the capsule. We finally obtained a global recovery rate of $94 \%$ (number of interpretable dosimeters/number of installed dosimeters). This demonstrates that passive dosimetry is a technique suitable for harsh outdoor volcanic conditions (windy, cold, humid and acid atmosphere).

\subsection{Spatial distribution of radon anomalies}

[13] All results and station details are given in Table 1 . The overall uncertainty on obtained ${ }^{222} \mathrm{Rn}$ activities varies between $14 \%$ and $38 \%$ with a mean value of $22 \%$ ( $2 \sigma$ relative uncertainty). Reference stations located far from the active crater zone (see Figure $1 \mathrm{~b}$ ) present a mean activity of $63 \pm 18 \mathrm{~Bq} / \mathrm{m}^{3}$ at ground level and a mean activity of $36 \pm 9 \mathrm{~Bq} / \mathrm{m}^{3}$ at a meter above the ground (free air). Higher values near the ground are not surprising because the only source of radon far from degassing vents 
$\mathrm{Bq} / \mathrm{m}^{3}$. Despite these wide ranges of values, geographical patterns can be observed. Figures $4 \mathrm{a}$ and $4 \mathrm{~b}$

represent the spatial distribution of integrated ground-level and free-air radon activities measured at

each station in the main four sectors of the crater rim (North-West, North-East, South-East and South-

West), as well as the wind directions during the exposure period. The main wind direction is from NW

to SE with an occurrence percentage $>80 \%$. It is noteworthy that the NW sector presents the lowest

elevations is found, even though the mean ground-level activity is slightly higher than the mean free-

air activity. Both NE and SW sectors show a very similar pattern with significantly higher ground-level

activities (155 \pm 43 and $186 \pm 62 \mathrm{~Bq} / \mathrm{m}^{3}$, respectively) but low free-air activities (75 \pm 10 and $90 \pm 15$

$\mathrm{Bq} / \mathrm{m}^{3}$, respectively) similar to those in the NW sector. Finally, the SE sector presents the highest mean 
[15] Ground-level radon anomalies observed both in the SW and NE sectors of the crater rim are coherent with the degassing phenomenology observed in the field. The SW sector of Mt. Etna's Central Crater mostly consists of a terrace covered by a massively altered yellow soil that likely results from the chemical alteration of basaltic rocks by acidic soil gases. The NE sector is a highly fractured zone (Marchese et al., 2018; see also Figure 1a) that also presents many features of severe soil alteration. Both sectors are sites of elevated soil $\mathrm{CO}_{2}$ diffuse degassing (Giammanco et al., 2016) that is likely associated with important radon soil emanations that can produce a significant radon anomaly at ground level. They are also areas of intense fumarolic activity as witnessed by the water vapor intensity seen in Sentinel images (see Figure 2). In marked contrast, important diffuse or fumarole degassing was not observed in the NW sector, which is in agreement with the low levels of radon activity measured close to ambient background.

[16] A hotspot of anomalous radon emission was also identified near the Voragine degassing vent (at the station located twenty meters upslope of the vent, see Figure 1a). At ground level, radon activity reaches $26,000 \mathrm{~Bq} / \mathrm{m}^{3}$ whereas at $1 \mathrm{~m}$ height, it is $8,800 \mathrm{~Bq} / \mathrm{m}^{3}$. No equivalent activity levels were found elsewhere around the crater including at stations adjacent to the hotspot site, and no progressive increase of radon activity towards it can be observed. It suggests that the hotspot is due to a very localized and peculiar structure, likely related to the strong degassing from the Voragine vent. In any case, this station was excluded from the computation of the sector mean radon activity. 

temporal evolution of radon activity at stations that were retrieved and immediately replaced in July

2018. Coherent patterns between the two periods of exposure can be observed for the different sectors, although only one pair of dosimeters (ground-level and free-air) has been collected and analyzed from each sector. For the two northern sector stations (NW and NE), free-air integrated radon activities decreased (NW) or increased (NE) by a factor of $\sim 2$ during the second period of exposure but remained within the range of reference values, in agreement with the hypothesis of limited influence of the gas plume. Ground-level activities increased by a factor of $\sim 3$ in both cases and exhibit values significantly higher than the reference level (Fig. 5a and 5b). This pattern could be tentatively

247 interpreted as resulting from enhanced soil degassing during the second period although a 248 meteorological effect, for instance due to an increased stability of the surface air layer, cannot be ruled out. The two southern sector stations (SW and SE) are both characterized by a decrease in radon activity at ground-level between the two periods (by a factor or $\sim 2$ ), hence producing values at the reference level (Fig. 5c and 5d). In marked contrast, free-air radon activities are significantly higher and above the reference value, which is especially obvious for the SE station where radon activity at $1 \mathrm{~m}$ above ground level is 15 times higher than during the first period of exposure. Such decoupling between ground-level and free-air activities excludes any interpretation based on a modification of the local soil radon flux (either from meteorological or volcanological origin). In which case, an even more important increase of ground-level activity should have been observed too. In fumaroles, 257 rainfalls can trigger positive radon anomalies but such induced radon enrichments usually are of much 258 lower magnitude (Zimmer and Erzinger, 2003). Furthermore, weather conditions during the whole 
period of the experiment were rather calm, with rare rainy events evenly distributed at the end of the

spring season and the beginning of the fall season. Since both wind direction and speed were similar during May-Jul and Jul-Oct periods (see Fig. 5e and 5f), it can thus be suggested that the tremendous increase in free-air radon activity observed at the SE station is related to the volcanic plume itself, especially because this station was installed in the windiest part of the SE sector (Fig. 4), downwind the active Bocca Nuova vents. Although sustained degassing activity occurred throughout the study period, it is worth noting that several signs of volcanic unrest were noticed, starting mid-July 2018 right after the new sets of dosimeters were installed around the crater rim. Evidences for this unrest may be found in the occurrence of strombolian explosions within the Central Crater (see also section 2 and Marchese et al., 2019), increasing thermal anomalies (Fig. 2), increasing $\mathrm{SO}_{2}$ fluxes (see Supplementary Material) and higher tremor with noticeable excursions into the red alert zone (e.g., Bollettino settimanale sul monitoraggio vulcanico, geochimico e sismico del vulcano Etna, 20/08/2018 $26 / 08 / 2018,2018)$. It thus suggests a correlation between stronger magmatic activity at the summit craters and increased radon activity in the air (and possibly also at the ground level) at the summit area of the volcano (see discussion hereafter).

\section{5) Discussion}

\subsection{Radon enrichments in Mt. Etna gas plume}

[18] In each summit sector of the volcano where the plume contribution is low or even virtually negligible (reference stations, NW, NE (including the Voragine hotspot) and SW sectors), the ratio of free-air to ground-level radon activities (termed hereafter air-soil ratio) range from $0.33 \pm 0.23$ to 0.86 

averages $2.34 \pm 0.85$. Together with the high mean free-air activity observed in the same sector, this suggests a significant radon enrichment in the crater plume compared to the atmospheric background, in agreement with a theoretical model that proposed high plume emissions of radon from openconduit volcanoes due to the persistent regeneration of radon in the degassing reservoir at depth by the decay of non-volatile ${ }^{226}$ Ra (Terray et al., 2018). In order to quantify this enrichment, the local contribution of soil degassing must be taken into account and subtracted. To do so, we assume that the air-soil ratio of $0.53 \pm 20$ represents the typical vertical gradient of radon activity in air from soil degassing in the absence of external aerial sources, which is in qualitative agreement with 1D vertical turbulent diffusion models (Jacobi and André, 1963). It can be tentatively assumed that such a vertical gradient also applies to the SE sector of Mt. Etna Central Crater. Therefore, it is possible to compute that the contribution from radon soil emanation at $1 \mathrm{~m}$ above ground level is $0.53 \times 301$ (mean ground level activity $)=160 \mathrm{~Bq} / \mathrm{m}^{3}$. Considering the average free air radon activity for the SE sector $\left(704 \mathrm{~Bq} / \mathrm{m}^{3}\right.$, Table 1), this leads to a radon enrichment in the plume of $704-160 \approx 550 \mathrm{~Bq} / \mathrm{m}^{3}$.

[19] This figure is the first direct estimate of radon activity in a gas plume released by an open-conduit volcano. Nonetheless, a previous study on Mount Erebus (Polian and Lambert, 1979) dealt with plume activities of aerosol-attached ${ }^{218} \mathrm{Po}$ (the first daughter of ${ }^{222} \mathrm{Rn}$ ) in the range $170-586 \mathrm{pCi} / \mathrm{m}^{3}(6.3-21.7$ $\left.\mathrm{Bq} / \mathrm{m}^{3}\right)$. The comparison of these two estimates is not straightforward since significant radioactive disequilibria prevail between radon and its first daughter in the lower atmosphere $\left(\left(^{218} \mathrm{Po} /{ }^{222} \mathrm{Rn}\right)\right.$ activity ratio as low as 0.45 during summertime, e.g. Kojima, 1996). Furthermore, a significant fraction of ${ }^{218} \mathrm{Po}$ atoms is not attached to aerosol particles and cannot be sampled by standard filtration 
methods (Tokonami et al., 1996), this fraction of unattached atoms being preponderant in watersaturated atmospheres like volcanic plumes. Accordingly, the estimate proposed by Polian and Lambert (1979) must be regarded as a minimum value. Conversely, our estimate of radon activity in the volcanic plume is one order of magnitude lower than that measured in mid-temperature fumarole discharges from VOR Crater (Giammanco et al., 2007). Because many fumaroles are located on the inner walls of the Central Crater and along the fracture swarm extending from North-East Crater to South-East Craters (Figure 1a), it cannot be ruled out that they contributed to the radon activity measured by our monitoring stations. This contribution however, likely remains moderate since active fissures in the SE sector are mostly located downslope the summit flank (Fig. 1a), so that dominant winds blow fumarolic gases away from our monitoring stations. Whatever be this contribution, the value of $550 \mathrm{~Bq} / \mathrm{m}^{3}$ for the bulk volcanic plume in the $\mathrm{SE}$ sector thus should be regarded as a maximum estimate, albeit realistic.

\subsection{Spatial variability of radon activity and degassing pathways}

[20] As previously discussed and apart from the Voragine hotspot, the highest radon activities were measured in the SE sector of the Central Crater, which is the most exposed area to the volcanic plume during the study period. Looking into more details, a significant variability of free-air radon activities is observed in this sector (Table 1). The three southernmost stations in the SE sector show relatively medium to high values (in the range $80-222 \mathrm{~Bq} / \mathrm{m}^{3}$ ) whereas the two northernmost stations measured up to $2500 \mathrm{~Bq} / \mathrm{m}^{3}$, the highest value recorded in free-air at the summit of Mt. Etna, with the exception of the VOR hotspot. These two latter stations were located not only in the windiest subsector of the 
SE sector (Fig. 4b), but also the closest to the BN2 vent, a few tens of meters downwind. Furthermore,

passive dosimeters at one of these two stations were retrieved in July 2018 and immediately replaced

by new ones. While radon activity at this station remained moderate between May and July $(73 \pm 20$

$\left.\mathrm{Bq} / \mathrm{m}^{3}\right)$, a sharp increase was noticed for the second period, peaking at $1091 \mathrm{~Bq} / \mathrm{m}^{3}$. Interestingly, the

the new vent could be associated with the observed radon increase during the second period of content of radon in the gas discharge from the new BN2 vent. No matter what scenario applies best, these results suggest that a change in the degassing process - through the opening of a new vent can be tracked through radon monitoring in air.

[21] The situation is rather different for the Voragine hotspot, where the highest radon activity is found at ground level. At this station, free-air radon activity could merely result from the vertical gradient of radon diffusion from soil to air at 1 meter above ground level (air-soil ratio of 0.33 ). The high radon activity at this place, thus, does not necessarily implies that the plume issued from VOR vent was particularly enriched in radon. Nevertheless, extremely high radon activities next to the VOR vent are not puzzling, even at ground level. This vent formed in August 2016 in a zone that was highly fractured by the 2015-2016 paroxysmal episodes at Voragine Crater. Before the vent opening, those fractures served as main pathways for soil gas emissions and fumarole discharges while the main degassing vents within the Voragine were still plugged (Marchese et al., 2018). When the radon monitoring station was installed in 2018 , we measured a soil temperature of $360^{\circ} \mathrm{C}$ at a depth of $30 \mathrm{~cm}$ with a Type $\mathrm{K}$ thermocouple placed within one sealed crack on the eastern rim of Voragine, just nearby the station 
that recorded the radon hotspot. Therefore we propose that the fissure swarm on the eastern rim of

342 Voragine was one of the most permeable part of the crater structure, allowing deep gas ascent, as

343 suggested for a previous eruptive cycle (Giammanco et al., 2007).

[22] As shown in Figures 5 a to $5 \mathrm{~d}$, a marked temporal evolution between the two exposure periods in

each sector of the volcano was observed. While ground-level emissions of radon appear slightly higher

during the second period on the northern side of Central Craters, free-air activities are markedly

enriched on the southern side, especially at that station most exposed to dominant wind in the SE

sector (Figure 5). It suggests that most radon emissions, either through soil degassing or by plume

outgassing, occurred during the period July-October 2018 when the volcano was more active. of $\mathrm{SO}_{2}$ flux is high, both mean and maximum $\mathrm{SO}_{2}$ fluxes are higher during the second period as well as the detrended cumulated $\mathrm{SO}_{2}$ flux values (see Supplementary Material). Although the time-evolution 
correlation with $\mathrm{SO}_{2}$ fluxes in a period of progressive unrest may give expectancies for the potential of

in-air radon measurements as a tracer of volcanic activity.

[23] Furthermore, while radon activity in the volcanic plume could be up to 15 times higher during the

July-October period (Table 1; Figure 5), it is worth noting that the $\mathrm{SO}_{2}$ flux showed a much more limited

Hence, despite slightly increased $\mathrm{SO}_{2}$ degassing during the second period, it can be assumed that the amount of magma degassing per unit of time did not drastically change between the two periods. In such a case, theoretical models predict that the flux of radon produced in the degassing magma is constant (Terray et al., 2018). However, because radon is a radio-isotope with a short half-life (3.8 days), radon activity in the gas phase can vary according to the transfer time of gases from the degassing reservoir to the surface (Terray et al., 2018). We can assume that the 15 times increase in radon activity between the two exposure periods was solely due to a transfer time variation, which would be the case if the mean plume dilution rate at the monitoring station was not significantly different for the two periods and if the contribution of steaming fumaroles was negligible. An increase in radon activity by a factor of 15 would be achieved in 3.9 radon half-lives. In other words, the

377 observed increase in radon activity could be explained by a transfer time of gases 15 days shorter after

378 the beginning of the July 2018 volcanic unrest. The ${ }^{210} \mathrm{~Pb}_{-}{ }^{210} \mathrm{Bi}^{210} \mathrm{Po}$ systematics in Mt. Etna gases

379 allowed estimating a gas transfer time in the range of 1-3 days during eruptive events (Terray et al., 2018) and up to 17 days during quiescent degassing (Lambert et al., 1985). Although the 15-day shorter 
eruptive activity was not triggered by an important reinjection of deep volatile-rich magma in the shallow plumbing system but instead by the shallower degassing of the already present magma batch (shorter transfer time of gases leading to higher radon activities). We propose that in-air ${ }^{222} \mathrm{Rn}$ activities - thanks to the radioactive properties of radon which make it sensitive to degassing kinetics and, hence, degassing depth - could be an interesting monitoring parameter in addition to $\mathrm{SO}_{2}$ and other geochemical and geophysical methods.

\subsection{Radiological effects and radon hazard assessment}

391

392

393

394

[24] The European regulations for public exposure to radon (EURATOM, 2013) recommend that radon activity in working places always remains below the threshold of $300 \mathrm{~Bq} / \mathrm{m}^{3}$ because of the potential damages of this radioactive gas to the respiratory system. Exposure to high levels of radon has been recognized as a major cause of lung cancer (Lubin et al., 1995). Two hotspots where radon activities exceed by far this threshold were found on the crater rim of Mt. Etna, on each side of the small hill between the Voragine and Bocca Nuova craters (Fig. 4b). Radon activities as high as $1 \mathrm{kBq} / \mathrm{m}^{3}$ are rare for outdoor environments and indicate that volcanic exhalations are a major source of radioactivity into the local air. Accordingly, the radon uptake through inhalation may be of concern for those people who either visit the volcano or work on it (e.g., volcano guides, scientists). Radon activities measured at one meter of elevation above the ground are the most relevant to assess the respiratory uptake. For activities between 1.1 and $8.8 \mathrm{kBq} / \mathrm{m}^{3}$ (Table 1), the radiological dose rate can be calculated in the 

be included in future studies on volcanic-gas-related health hazards.

range $16-131 \mu \mathrm{Sv} / \mathrm{h}$ using a conversion coefficient of $1,5 \cdot 10^{-5} \mathrm{mSv}$ per Bq.h.m $\mathrm{m}^{-3}$ (obtained from a dose coefficient of $6,7 \mathrm{mSv}$ per mJ.h. $\mathrm{m}^{-3}$ and an equilibrium factor of 0.4 between radon and its daughters) as recommended by the International Commission on Radiological Protection (norm 137, Paquet et al., 2017). For tourists spending a few tens of minutes at the summit of Mt. Etna once in a lifetime, the equivalent dose transmitted to their body remains very low and most likely harmless. For instance, a tourist walking on the path around the Central Crater, spending 10 minutes close to the Voragine hotspot and 20 minutes on the southern slope, would receive a dose of ca. $27 \mu \mathrm{Sv}$, which is only $2 \%$ of the worldwide typical yearly exposure to radon. However, for volcano guides spending up to 4 hours per day at the summit of the volcano, this on a daily basis all the touristic season long, the dose rate may be significantly higher. In a probable scenario of 30 minutes exposure at the identified radon hotspots once a day, the received radiological dose can be computed as: $\left(131 \times 10^{\prime} / 60^{\prime}+16 \times 20^{\prime} / 60^{\prime}\right) \times$ $10^{-3}$ (mSv/working day) $\times 100$ (working day/y) (assuming the season peak lasts from early May to late September with 5 working days a week) $=2.7 \mathrm{mSv} / \mathrm{yr}$. This value is twice higher than the typical exposure due to radon (1.26 mSv/yr, UNSCEAR, 2008). Although many other factors - out of the scope of the present study - should be considered in order to refine this assessment (radon daughters concentrations, radioactive aerosol particle size distribution, exact duration of exposure, use of individual protective devices such as gas masks), the present study strongly suggests that radon should 
423 [25] This first experiment of radon dosimetry in air at an active volcano revealed free-air radon levels

424 significantly higher than the atmospheric background in the zones most exposed to volcanic gases (up

425 to a few $\mathrm{kBq} / \mathrm{m}^{3}$ ). Radon in such a dynamic environment could come from diffuse soil degassing, low-

426 to mid-temperature steaming fumaroles and from the main gas plume made of primary magmatic

427 vapor. In the lack of a detailed knowledge of local meteorological effects inside the Central Crater of

428 Mt. Etna, the contribution of each potential source of radon could not be deciphered. However, in the

429 SE sector of the Central Crater, the most exposed to the volcanic plume because of the main regional

430 NW wind, a significant radon enrichment was measured in air at $1 \mathrm{~m}$ above the ground. This

431 observation strongly supports high radon concentrations in the main gas plume $\left(\approx 550 \mathrm{~Bq} / \mathrm{m}^{3}\right)$. This is

432 the first direct evidence of primary magmatic gases being significantly enriched in radon, which implies

433 that radon does not completely decay away within magmatic gas bubbles before reaching the surface.

434 The transfer time of gases between the degassing reservoir and the surface is thus as short as a few days, or a few weeks at most, thus supporting previous theoretical studies.

[26] The main degassing pathways, either through open vents or through fracture systems, are

437 markedly identified by radon hotspots with free-air activities above $1,000 \mathrm{~Bq} / \mathrm{m}^{3}$ and up to 8,800

$438 \mathrm{~Bq} / \mathrm{m}^{3}$. This observation confirms that radon is a useful geochemical tracer of shallow degassing processes at active volcanoes. Furthermore, an increase of radon free-air activity in the SE sector, most exposed to the crater plume, was observed during an episode of eruptive activity, starting in July 2018 
radon activities increased up to 15 times during the volcanic unrest. Such pattern is best explained by

443 a 15-day shorter transfer time of gases from a constant volume of magma, or in other words by

444 degassing occurring at shallower depth beneath the active craters. The results of the study should

445 encourage further studies on radon in volcanic plumes in order to fully appraise the potential of radon

446 monitoring in ambient air at active volcanoes as a useful tool for volcano monitoring, in complement

447 to other geochemical and geophysical parameters. While passive dosimetry appears of interest as an

448 easy-to-deploy and cheap technology to characterize the baseline of in-air radon activities, efficient

449 volcanic monitoring will require more sophisticated technologies with near-real time response (e.g.,

450 Terray et al., 2020). In particular, it will be of the utmost importance to quantify radon fluxes of primary

451 magmatic origin and to understand how they may vary in relation with shallow magma dynamics.

452 [27] Finally, radon activities higher than $1 \mathrm{kBq} / \mathrm{m}^{3}$ found at some places of Mt. Etna summit area could

453 cause health concern for regular workers on the volcano. Further studies should be devoted to a

454 detailed radiological study of exposure to radon of volcanic origin in order to propose individual actions

455 leading to a mitigation of potential health effects.

\section{Contributions and Acknowledgments}

[28] LT, VB and PJG designed the passive dosimetry experiment and set it in the field with the help of 
contributed to the ideas presented in this paper and to its writing. We thank the Associate Editor and

anonymous reviewers for their meaningful suggestions and comments which led to improve the

manuscript.

[29] The scientific support of INGV - Osservatorio Etneo and the logistical help provided by both Parco

This is Laboratory of Excellence ClerVolc contribution number XXX [NB: ClerVolc number will be

communicated once the manuscript is accepted for publication].

[30] In order to comply with FAIR standards, the two datasets presented in the manuscript (radon

Aiuppa, A., Giudice, G., Gurrieri, S., Liuzzo, M., Burton, M., Caltabiano, T., McGonigle, A.J.S., Salerno, G., Shinohara, H., Valenza, M., 2008. Total volatile flux from Mount

Allard, P., Aiuppa, A., Bani, P., Métrich, N., Bertagnini, A., Gauthier, P.-J., Shinohara, H., Sawyer, G., Parello, F., Bagnato, E., Pelletier, B., Garaebiti, E., 2016. Prodigious emission rates and magma degassing budget of major, trace and radioactive volatile species from Ambrym basaltic volcano, Vanuatu island Arc. Journal of Volcanology 
and Geothermal Research, Understanding volcanoes in the Vanuatu arc 322, 119-143. https://doi.org/10.1016/j.jvolgeores.2015.10.004

Andres, R., Rose, W., Stoiber, R., Williams, S., Matías, O., Morales, R., 1993. A summary of sulfur dioxide emission rate measuremnts from Guatemalan volcanoes. Bull Volcanol 55, 379-388. https://doi.org/10.1007/BF00301150

Berlo, K., Turner, S., Blundy, J., Black, S., Hawkesworth, C., 2006. Tracing pre-eruptive magma degassing using $(210 \mathrm{~Pb} / 226 \mathrm{Ra})$ disequilibria in the volcanic deposits of the 1980-1986 eruption of Mount St. Helens. Earth and Planetary Science Letters 249, 337-349. https://doi.org/10.1016/j.epsl.2006.07.018

Bollettino settimanale sul monitoraggio vulcanico, geochimico e sismico del vulcano Etna, 20/08/2018 - 26/08/2018, 2018. INGV-OE.

Bonaccorso, A., Calvari, S., Coltelli, M., Del Negro, C., Falsaperla, S., 2004. Mt. Etna: Volcano Laboratory. Washington DC American Geophysical Union Geophysical Monograph Series 143. https://doi.org/10.1029/GM143

Campion, R., Salerno, G.G., Coheur, P.-F., Hurtmans, D., Clarisse, L., Kazahaya, K., Burton, M., Caltabiano, T., Clerbaux, C., Bernard, A., 2010. Measuring volcanic degassing of $\mathrm{SO} 2$ in the lower troposphere with ASTER band ratios. Journal of Volcanology and Geothermal Research 194, 42-54. https://doi.org/10.1016/j.jvolgeores.2010.04.010

Chirkov, A.M., 1975. Radon as a possible criterion for predicting eruptions as observed at Karymsky volcano. Bull Volcanol 39, 126-131. https://doi.org/10.1007/BF02596952

Cigolini, C., Laiolo, M., Coppola, D., Trovato, C., Borgogno, G., 2016. Radon surveys and monitoring at active volcanoes: learning from Vesuvius, Stromboli, La Soufrière and Villarrica. Geological Society, London, Special Publications 451, 183-208. https://doi.org/10.1144/SP451.1

Condomines, M., Sigmarsson, O., Gauthier, P.J., 2010. A simple model of 222Rn accumulation leading to $210 \mathrm{~Pb}$ excesses in volcanic rocks. Earth and Planetary Science Letters 293, 331-338. https://doi.org/10.1016/j.epsl.2010.02.048

Corsaro, R.A., Andronico, D., Behncke, B., Branca, S., Caltabiano, T., Ciancitto, F., Cristaldi, A., De Beni, E., La Spina, A., Lodato, L., Miraglia, L., Neri, M., Salerno, G., Scollo, S., Spata, G., 2017. Monitoring the December 2015 summit eruptions of Mt. Etna (Italy): Implications on eruptive dynamics. Journal of Volcanology and Geothermal Research 341, 53-69. https://doi.org/10.1016/j.jvolgeores.2017.04.018

De Beni, E., Cantarero, M., Messina, A., 2019. UAVs for volcano monitoring: A new approach applied on an active lava flow on Mt. Etna (Italy), during the 27 February02 March 2017 eruption. Journal of Volcanology and Geothermal Research 369, 250 262. https://doi.org/10.1016/j.jvolgeores.2018.12.001

De Novellis, V., Atzori, S., Luca, C.D., Manzo, M., Valerio, E., Bonano, M., Cardaci, C., Castaldo, R., Bucci, D.D., Manunta, M., Onorato, G., Pepe, S., Solaro, G., Tizzani, P., Zinno, I., Neri, M., Lanari, R., Casu, F., 2019. DInSAR Analysis and Analytical Modeling of Mount Etna Displacements: The December 2018 Volcano-Tectonic Crisis. Geophysical Research Letters 46, 5817-5827. https://doi.org/10.1029/2019GL082467

Delmelle, P., Stix, J., Baxter, P., Garcia-Alvarez, J., Barquero, J., 2002. Atmospheric dispersion, environmental effects and potential health hazard associated with the lowaltitude gas plume of Masaya volcano, Nicaragua. Bull Volcanol 64, 423-434. https://doi.org/10.1007/s00445-002-0221-6

EURATOM, 2013. Directive laying down basic safety standards for protection against the dangers arising from exposure to ionising radiation [WWW Document]. URL https://eur-lex.europa.eu/eli/dir/2013/59/oj (accessed 10.9.19). 
Gauthier, P.-J., Condomines, M., 1999. 210Pb-226Ra radioactive disequilibria in recent lavas and radon degassing: inferences on the magma chamber dynamics at Stromboli and Merapi volcanoes. Earth and Planetary Science Letters 172, 111-126. https://doi.org/10.1016/S0012-821X(99)00195-8

Gauthier, P.-J., Condomines, M., Hammouda, T., 1999. An experimental investigation of radon diffusion in an anhydrous andesitic melt at atmospheric pressure: implications for radon degassing from erupting magmas. Geochimica et Cosmochimica Acta 63, 645-656. https://doi.org/10.1016/S0016-7037(98)00305-6

Gauthier, P.-J., Le Cloarec, M.-F., Condomines, M., 2000. Degassing processes at Stromboli volcano inferred from short-lived disequilibria $(210 \mathrm{~Pb}-210 \mathrm{Bi}-210 \mathrm{Po})$ in volcanic gases. Journal of Volcanology and Geothermal Research 102, 1-19. https://doi.org/10.1016/S0377-0273(00)00179-7

Gauthier, P.-J., Sigmarsson, O., Gouhier, M., Haddadi, B., Moune, S., 2016. Elevated gas flux and trace metal degassing from the 2014-2015 fissure eruption at the Bárðarbunga volcanic system, Iceland. Journal of Geophysical Research: Solid Earth 121, 1610 1630. https://doi.org/10.1002/2015JB012111

Giammanco, S., Melián, G., Neri, M., Hernández, P.A., Sortino, F., Barrancos, J., López, M., Pecoraino, G., Perez, N.M., 2016. Active tectonic features and structural dynamics of the summit area of Mt. Etna (Italy) revealed by soil CO2 and soil temperature surveying. Journal of Volcanology and Geothermal Research 311, 79-98. https://doi.org/10.1016/j.jvolgeores.2016.01.004

Giammanco, S., Sims, K.W.W., Neri, M., 2007. Measurements of 220Rn and 222Rn and CO2 emissions in soil and fumarole gases on Mt. Etna volcano (Italy): Implications for gas transport and shallow ground fracture. Geochemistry, Geophysics, Geosystems 8. https://doi.org/10.1029/2007GC001644

Gill, J., Williams, R., Bruland, K., 1985. Eruption of basalt and andesite lava degasses 222Rn and 210Po. Geophysical Research Letters 12, 17-20. https://doi.org/10.1029/GL012i001p00017

Hansell, A., Oppenheimer, C., 2004. Health Hazards from Volcanic Gases: A Systematic Literature Review. Archives of Environmental Health: An International Journal 59, 628-639. https://doi.org/10.1080/00039890409602947

Jacobi, W., André, K., 1963. The vertical distribution of radon 222, radon 220 and their decay products in the atmosphere. Journal of Geophysical Research (1896-1977) 3799-3814. https://doi.org/10.1029/JZ068i013p03799@10.1002/(ISSN)2156-2202.TGNARA1

Lambert, G., Bristeau, P., Polian, G., 1976. Emission and enrichments of radon daughters from Etna Volcano magma. Geophysical Research Letters 3, 724-726. https://doi.org/10.1029/GL003i012p00724

Lambert, G., Le Cloarec, M.F., Ardouin, B., Le Roulley, J.C., 1985. Volcanic emission of radionuclides and magma dynamics. Earth and Planetary Science Letters 76, 185-192. https://doi.org/10.1016/0012-821X(85)90158-X

Le Cloarec, M.-F., Gauthier, P.-J., 2003. Merapi Volcano, Central Java, Indonesia: A case study of radionuclide behavior in volcanic gases and its implications for magma dynamics at andesitic volcanoes: RADIONUCLIDE BEHAVIOR IN VOLCANIC GASES. Journal of Geophysical Research: Solid Earth 108. https://doi.org/10.1029/2001JB001709

Le Cloarec, M.F., Pennisi, M., 2001. Radionuclides and sulfur content in Mount Etna plume in 1983-1995: new constraints on the magma feeding system. Journal of Volcanology and Geothermal Research 108, 141-155. https://doi.org/10.1016/S03770273(00)00282-1 
Liotta, M., Paonita, A., Caracausi, A., Martelli, M., Rizzo, A., Favara, R., 2010. Hydrothermal processes governing the geochemistry of the crater fumaroles at Mount Etna volcano (Italy). Chemical Geology 278, 92-104. https://doi.org/10.1016/j.chemgeo.2010.09.004

Lubin, J.H., Boice, J.D., Edling, C., Hornung, R.W., Howe, G.R., Kunz, E., Kusiak, R.A., Morrison, H.I., Radford, E.P., Samet, J.M., Tirmarche, M., Woodward, A., Yao, S.X., Pierce, D.A., 1995. Lung Cancer in Radon-Exposed Miners and Estimation of Risk From Indoor Exposure. J Natl Cancer Inst 87, 817-827. https://doi.org/10.1093/jnci/87.11.817

Marchese, F., Genzano, N., Neri, M., Falconieri, A., Mazzeo, G., Pergola, N., 2019. A MultiChannel Algorithm for Mapping Volcanic Thermal Anomalies by Means of Sentinel-2 MSI and Landsat-8 OLI Data. Remote Sensing 11, 2876. https://doi.org/10.3390/rs11232876

Marchese, F., Neri, M., Falconieri, A., Lacava, T., Mazzeo, G., Pergola, N., Tramutoli, V., 2018. The Contribution of Multi-Sensor Infrared Satellite Observations to Monitor Mt. Etna (Italy) Activity during May to August 2016. Remote Sensing 10, 1948. https://doi.org/10.3390/rs10121948

Mollo, S., Tuccimei, P., Soligo, M., Galli, G., Scarlato, P., 2018. Chapter 18 - Advancements in Understanding the Radon Signal in Volcanic Areas: A Laboratory Approach Based on Rock Physicochemical Changes, in: Samui, P., Kim, D., Ghosh, C. (Eds.), Integrating Disaster Science and Management. Elsevier, pp. 309-328. https://doi.org/10.1016/B978-0-12-812056-9.00018-X

Monnin, M.M., 2001. Radon Over Volcanic and Seismic Areas, in: Frontasyeva, M.V., Perelygin, V.P., Vater, P. (Eds.), Radionuclides and Heavy Metals in Environment, NATO Science Series. Springer Netherlands, Dordrecht, pp. 319-330. https://doi.org/10.1007/978-94-010-0993-5_44

Morales-Simfors, N., Wyss, R.A., Bundschuh, J., 2020. Recent progress in radon-based monitoring as seismic and volcanic precursor: A critical review. Critical Reviews in Environmental Science and Technology 50, 979-1012. https://doi.org/10.1080/10643389.2019.1642833

Neri, M., Ferrera, E., Giammanco, S., Currenti, G., Cirrincione, R., Patanè, G., Zanon, V., 2016. Soil radon measurements as a potential tracer of tectonic and volcanic activity. Scientific Reports 6, 24581. https://doi.org/10.1038/srep24581

Neri, M., Maio, M.D., Crepaldi, S., Suozzi, E., Lavy, M., Marchionatti, F., Calvari, S., Buongiorno, M.F., 2017. Topographic Maps of Mount Etna's Summit Craters, updated to December 2015. Journal of Maps 13, 674-683. https://doi.org/10.1080/17445647.2017.1352041

Paquet, F., Bailey, M.R., Leggett, R.W., Lipsztein, J., Marsh, J., Fell, T.P., Smith, T., Nosske, D., Eckerman, K.F., Berkovski, V., 2017. ICRP Publication 137: Occupational Intakes of Radionuclides: Part 3. Annals of the ICRP 46, 1-486.

Salerno, G.G., Burton, M., Di Grazia, G., Caltabiano, T., Oppenheimer, C., 2018. Coupling Between Magmatic Degassing and Volcanic Tremor in Basaltic Volcanism. Front. Earth Sci. 6. https://doi.org/10.3389/feart.2018.00157

Salerno, G.G., Burton, M.R., Oppenheimer, C., Caltabiano, T., Randazzo, D., Bruno, N., Longo, V., 2009a. Three-years of SO2 flux measurements of Mt. Etna using an automated UV scanner array: Comparison with conventional traverses and uncertainties in flux retrieval. Journal of Volcanology and Geothermal Research 183, 76-83. https://doi.org/10.1016/j.jvolgeores.2009.02.013

Salerno, G.G., Burton, M.R., Oppenheimer, C., Caltabiano, T., Tsanev, V.I., Bruno, N., $2009 \mathrm{~b}$. Novel retrieval of volcanic SO2 abundance from ultraviolet spectra. Journal of 
Volcanology and Geothermal Research 181, 141-153.

https://doi.org/10.1016/j.jvolgeores.2009.01.009

Sato, K., Kaneoka, I., Sato, J., 1980. Rare-gas releasing experiments and Rn degassing from erupting magma. Geochemical Journal 14, 91-94. https://doi.org/10.2343/geochemj.14.91

Scollo, S., Prestifilippo, M., Pecora, E., Corradini, S., Merucci, L., Spata, G., Coltelli, M., 2014. Eruption column height estimation of the 2011-2013 Etna lava fountains. Annals of Geophysics 57, 0214. https://doi.org/10.4401/ag-6396

Seidel, J.L., Monnin, M., 1984. Mesures de Radon-222 dans le sol de l'Etna (Sicile): 19801983. Bull Volcanol 47, 1071-1077. https://doi.org/10.1007/BF01952363

Sigmarsson, O., Condomines, M., Gauthier, P.-J., 2015. Excess 210Po in 2010 Eyjafjallajökull tephra (Iceland): Evidence for pre-eruptive gas accumulation. Earth and Planetary Science Letters 427, 66-73. https://doi.org/10.1016/j.eps1.2015.06.054

Sources and effects of ionizing radiation, UNSCEAR 2008 Report, 2010. . Volume I. Annex A. United Nations, New York.

Terray, L., Gauthier, P.-J., Salerno, G., Caltabiano, T., La Spina, A., Sellitto, P., Briole, P., 2018. A New Degassing Model to Infer Magma Dynamics from Radioactive Disequilibria in Volcanic Plumes. Geosciences 8, 27. https://doi.org/10.3390/geosciences 8010027

Terray, L., Royer, L., Sarramia, D., Achard, C., Bourdeau, E., Chardon, P., Claude, A., Fuchet, J., Gauthier, P.-J., Grimbichler, D., Mezhoud, J., Ogereau, F., Vandaële, R., Breton, V., 2020. From Sensor to Cloud: An IoT Network of Radon Outdoor Probes to Monitor Active Volcanoes. Sensors 20, 2755. https://doi.org/10.3390/s20102755

Tokonami, S., Iimoto, T., Kurosawa, R., 1996. Continuous measurement of the equilibrium factor $\mathrm{F}$ and the unattached fraction $\mathrm{fp}$ of radon progeny in the environment. Environment International, The Natural Radiation Environment VI 22, 611-616. https://doi.org/10.1016/S0160-4120(96)00163-8

Vaupotič, J., Žvab, P., Giammanco, S., 2010. Radon in outdoor air in the Mt. Etna area, Italy. Nukleonika Vol. 55, No. 4, 573-577.

Wu, Z., Huang, N.E., Long, S.R., Peng, C.-K., 2007. On the trend, detrending, and variability of nonlinear and nonstationary time series. Proceedings of the National Academy of Sciences 104, 14889-14894.

Zimmer, M., Erzinger, J., 2003. Continuous H2O, CO2, 222Rn and temperature measurements on Merapi Volcano, Indonesia. Journal of Volcanology and Geothermal Research, Understanding volcanoes through multiparameter measurements and their interpretation: In memory of Bruno Martinelli 125, 25-38. https://doi.org/10.1016/S0377-0273(03)00087-8 
676

677

678

679

680

681

682

683 Figures and tables 

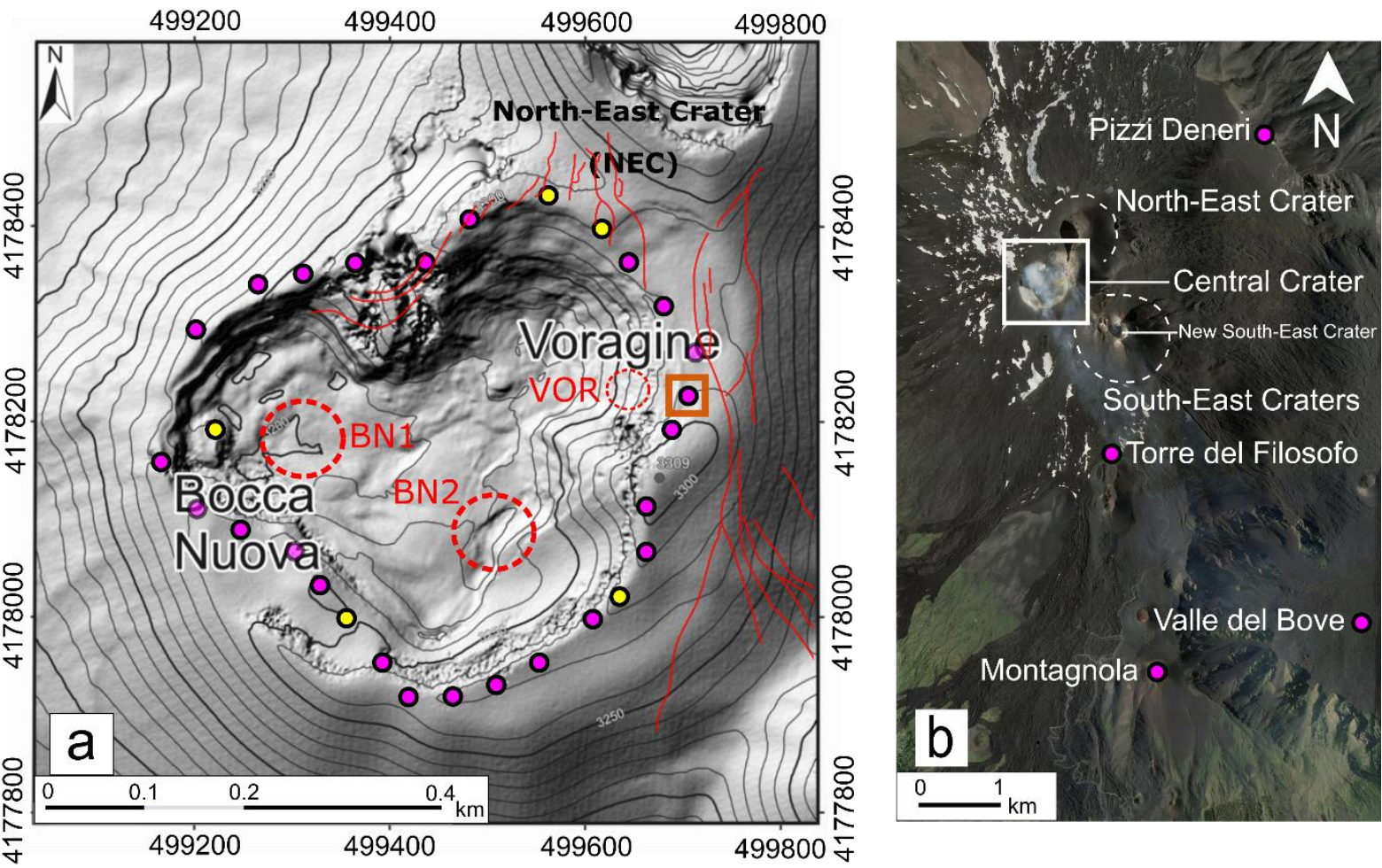

Figure 1: (a) Map of the summit craters of Mt. Etna (modified from Neri et al., 2017) with the location of the radon dosimetry stations (yellow dots represent the stations that were replaced in July and purple dots the other stations). Dotted red circles represent the degassing vents active during the period of exposure of dosimeters. VOR stands for the Voragine vent and BN1-BN2 for the two Bocca Nuova vents. The radon hotspot in front of VOR vent (see text for details) is indicated with an orange frame. Red lines depict the main North-South fractures formed on the rim after the May 2016 eruption (drawn after Marchese et al., 2018) (b) Wider view of Mt. Etna summit area (extracted from Google Earth) with the position of the four remote reference dosimetry stations. The white frame corresponds to the map in (a). 


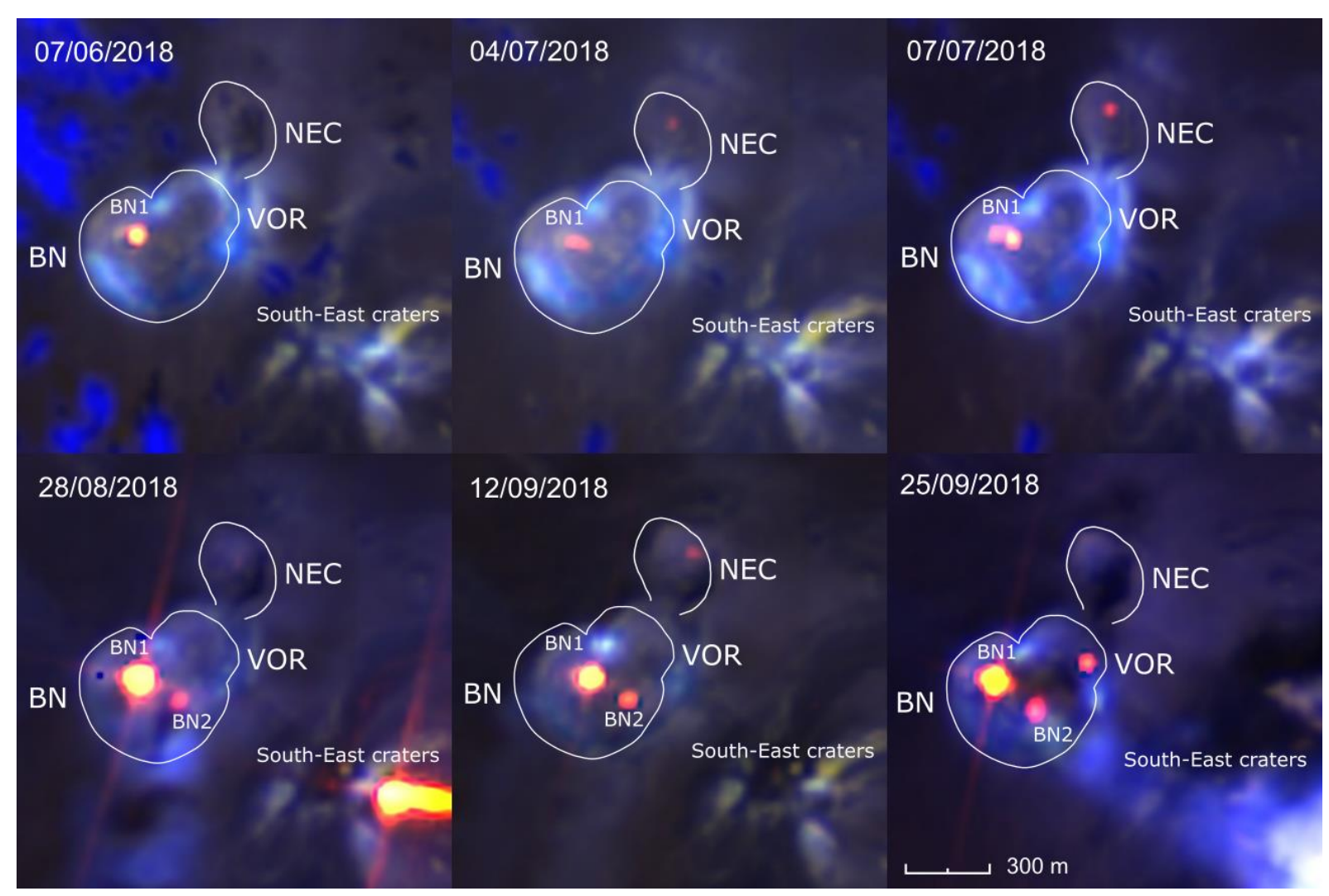

Figure 2: Mt. Etna summit craters seen from Sentinel $2 B$ satellite during summer 2018. Images on the top correspond with the first exposure period (24/05/18-06/07/18, the last image has been captured one day after on 07/07/2018) and images on the bottom correspond to the second period (06/07/18-11/10/18). Images have been produced using a combination of bands from the L2A level (orthorectified bottom-of-atmosphere reflectance) as follows: Red (Band 12 - Short Wave Infra Red - $2190 \mathrm{~nm}$ ) - Green (Band 11 - Short Wave Infra Red - $1610 \mathrm{~nm}$ ) - Blue (Band 9-Water vapour - $945 \mathrm{~nm}$ ). The spatial resolution is $20 \mathrm{~m}$ for bands 12 and 11 but $60 \mathrm{~m}$ for band 9 . Sentinel products are made publicly available by the European Spatial Agency on its website (https://apps.sentinel-hub.com/eo-browser/). Red and yellow pixels highlight positive infrared thermal anomalies that correspond to the precise location of degassing vents BN1 (Bocca Nuova 1), BN2 (Bocca Nuova 2) and VOR (Voragine), possibly related to the presence of very shallow magma. The gas plume escaping from the crater, as well as the main fumarole fields, are also visible in blue due to their high water content. 


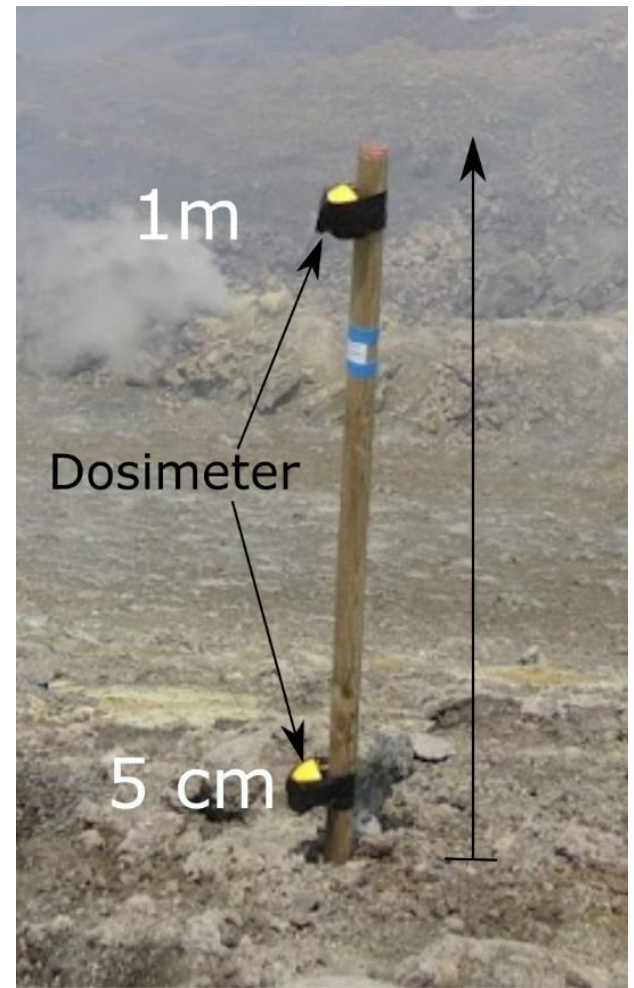

Figure 3: Image of a station installed on the rim of Etna Central Crater. Two dosimeters are fixed to a wooden stick anchored 
Figure 4: Spatial distribution of ground level $(5 \mathrm{~cm}$, left panel) and in free air (1 $\mathrm{m}$, right panel) integrated radon activities measured in the four different sectors of Mt. Etna Central Crater. References stations are represented separately below each panel. All crater stations are positioned according to the geographical coordinates given in Table 1. Coordinates are displayed using an UTM (Universal Transverse Mercator) projection relatively to the center of the Central Crater (barycenter of all station locations). Black star symbols correspond to stations where radon activities could be determined, black cross symbols correspond to stations where no radon activity is available (see text for explanations) and the red star symbol correspond to the Voragine hotspot station (see text). Radon activity values are indicated next to each station pictogram and for the few stations replaced in July 2018 the time-weighted mean value over the two exposure periods is given. A colored band is also drawn to reflect the spatial distribution of activity values. The color sequence all around the crater is obtained from a linear interpolation of measured activity in angular coordinates. Voragine station outlier values are excluded from the color band and the colorscale is logarithmic. The wind rose obtained from Trapani radiosounding (see text for details) is also represented with a polar histogram. Circles correspond to iso-lines of percentage of occurrence for wind directions. The bin color refer to the wind speed (see legend on the right side). 

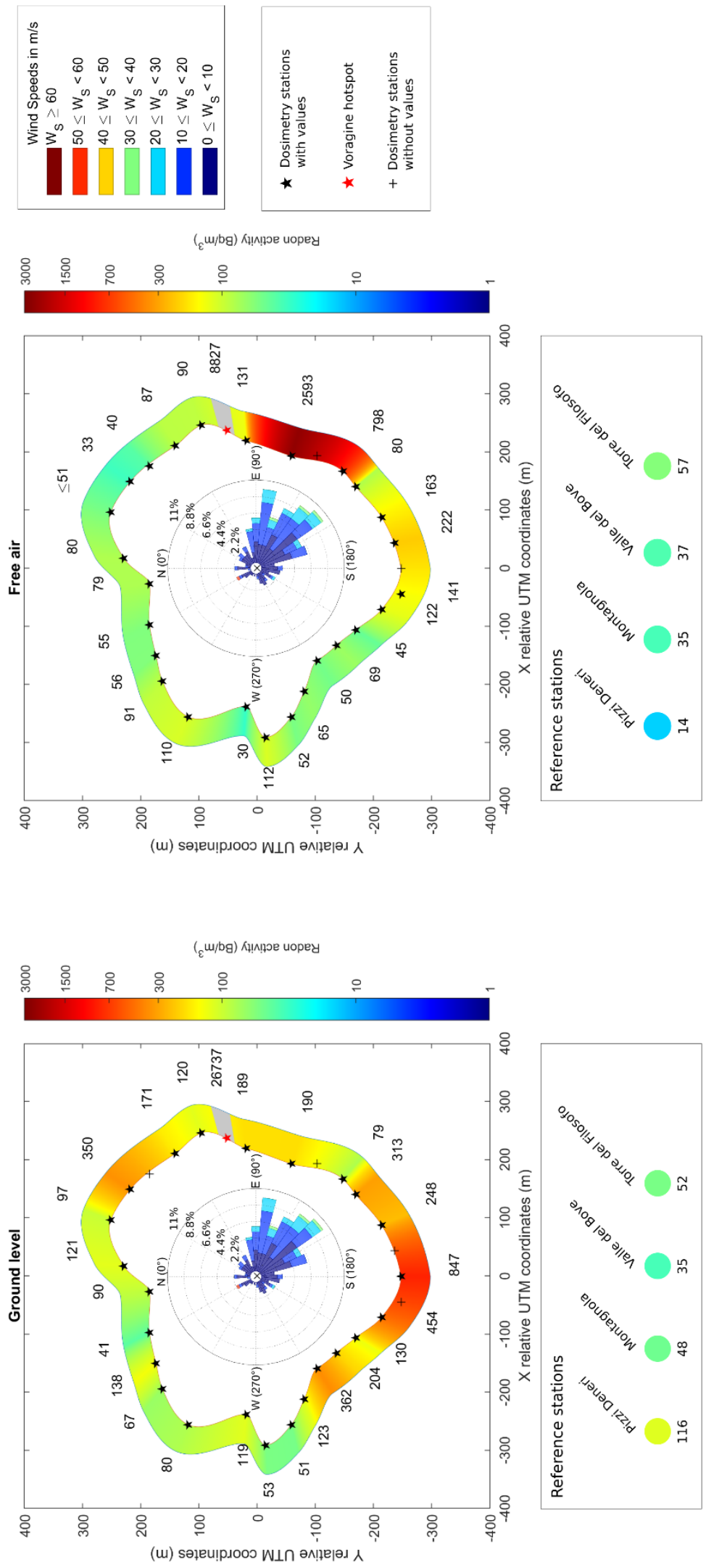
(a) NW

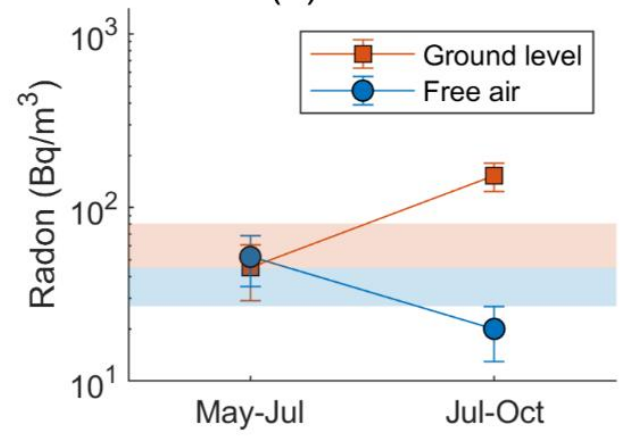

(c) SE

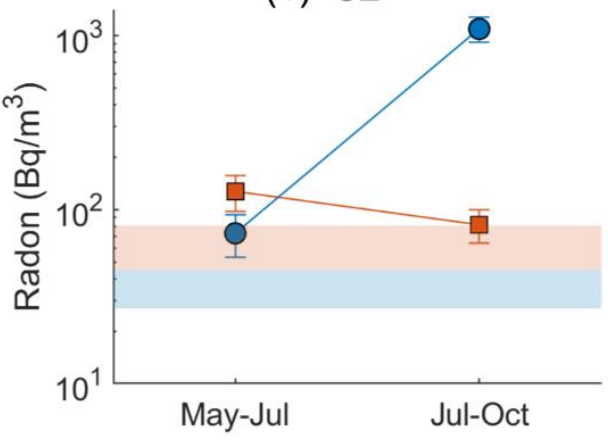

(e)

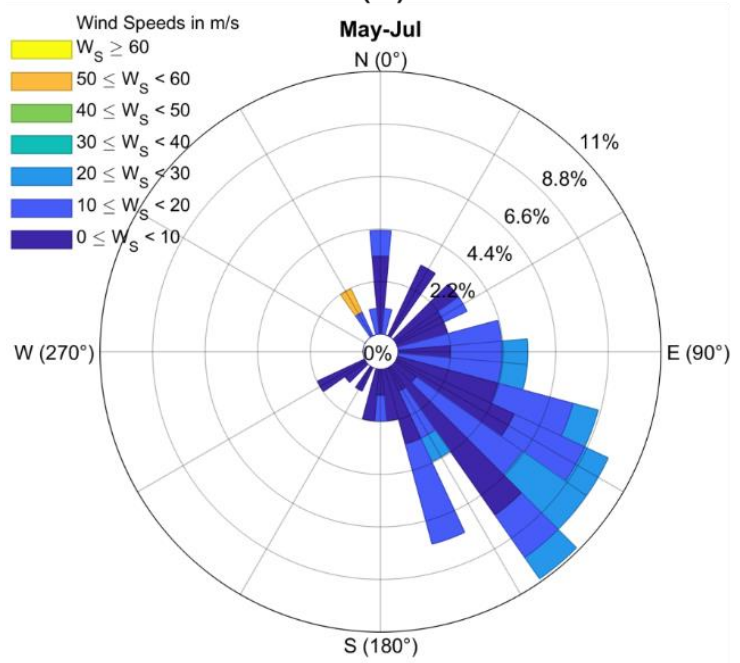

(b) NE

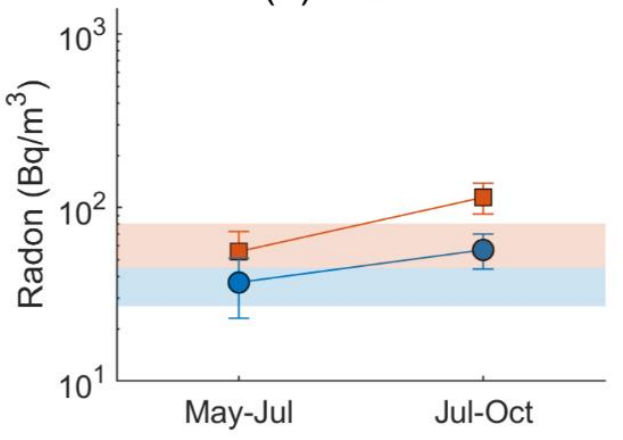

(d) $\mathrm{sw}$

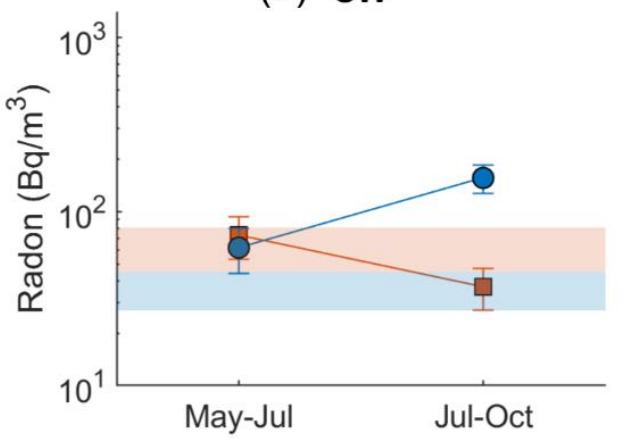

(f)

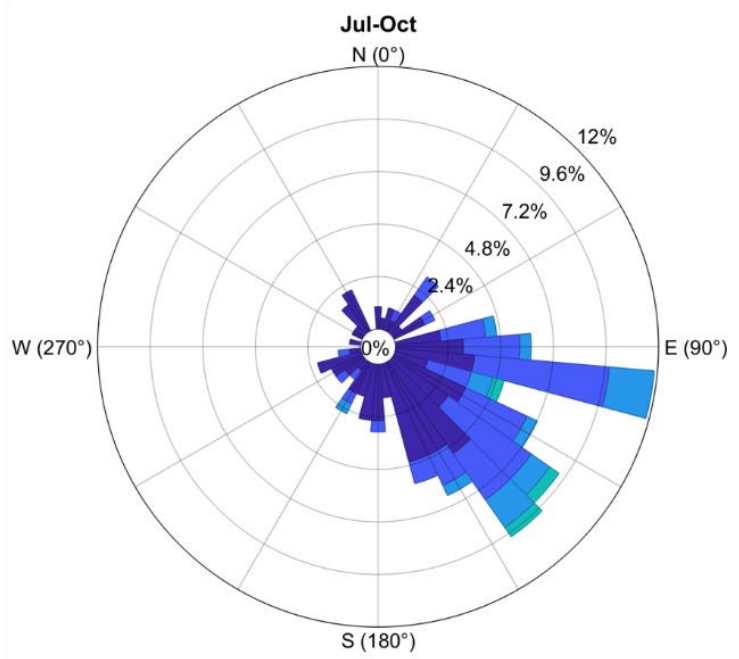

Figure 5: Comparison of ${ }^{222} \mathrm{Rn}$ activity (Fig. $5 a$ to 5d) and wind (Fig. 5e and 5f) between May-July 2018 and July-October 2018 periods. (a) to (d) - Comparison of ${ }^{222} \mathrm{Rn}$ integrated activity between the two periods for each of the four stations that were replaced in July 2018 (one for each sector of the crater rim). Ground level activities correspond to orange square symbols, whereas free-air activities are depicted in blue dot points. Ground-level and free-air reference activities measured at remote locations (mean values are given in Table 1) are also indicated in the plot background with orange and blue colors, respectively. The same wooden stick was used for the two measurement periods at all stations, except on the NE sector where the new station was positioned a few meters away from the former emplacement because of a potential risk of destruction due to combustion of the wood. (e) and (f) - Comparison of wind direction and speed between May-July 2018 and July-October 2018. For both periods the mean speed was $10 \mathrm{~m} / \mathrm{s}$ with a standard deviation of $7 \mathrm{~m} / \mathrm{s}$. 
Table 1 (next page): Radon dosimeter results with uncertainty for each dosimeter given at confidence interval of 2- $\sigma$. For the mean values, uncertainty corresponds to the standard error (standard deviation of the population divided by the square root of the number of elements in the population). Exposure periods started and ended as follows: May-Oct (24/05/18-11/10/18), May-Jul (24/05/1806/07/18) and Jul-Oct (06/07/18-11/10/18). "lost" indicates a dosimeter that was lost during the experiment, "udl" refers to a dosimeter that yielded results under the detection limit, and "damaged" corresponds to a dosimeter that was corroded by acids and could not be analyzed or that was clogged in soldered dust preventing radon from entering the capsule. Note that one station (namely, that

810 closest to the Voragine vent) was excluded from the computation of the mean value of the NE sector 811 (see text for explanation). 
Integrated radon activity $\left(\mathrm{Bq} / \mathrm{m}^{3}\right)$

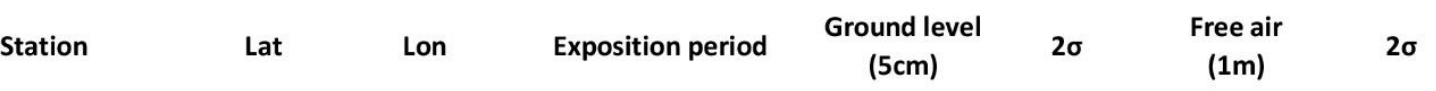

\begin{tabular}{lrrrrrrr}
\hline \hline & \multicolumn{7}{c}{ References sites } \\
& & & & & & & \\
Pizzi Deneri & 37.7636 & 15.0193 & May-Oct & 116 & 22 & 14 & 5 \\
Montagnola & 37.7177 & 15.0066 & May-Oct & 48 & 10 & 35 & 8 \\
Valle del Bove & 37.7206 & 15.0334 & Jul-Oct & 35 & 10 & 37 & 10 \\
Torre del Filosofo & 37.7368 & 15.0006 & May-Oct & 52 & 11 & 57 & 12 \\
Reference mean & & & & $\mathbf{6 3}$ & $\mathbf{1 8}$ & $\mathbf{3 6}$ & $\mathbf{9}$ \\
\hline
\end{tabular}

\begin{tabular}{lll} 
North West sector & 37.7508 & 14.9905 \\
North West sector & 37.7511 & 14.9911 \\
North West sector & 37.7520 & 14.9909 \\
North West sector & 37.7524 & 14.9916 \\
North West sector & 37.7525 & 14.9921 \\
North West sector & 37.7526 & 14.9927 \\
NW sector mean & & \\
\hline
\end{tabular}

\section{North West sector}

\begin{tabular}{lrrrr} 
May-Oct & 53 & 12 & 112 & 21 \\
May-Jul & 45 & 16 & 52 & 17 \\
Jul-Oct & 152 & 29 & 20 & 7 \\
May-Oct & 80 & 16 & 110 & 21 \\
May-Oct & 67 & 14 & 91 & 18 \\
May-Oct & 138 & 25 & 56 & 12 \\
May-Oct & 41 & 10 & 55 & 12 \\
& $\mathbf{8 2}$ & $\mathbf{1 7}$ & $\mathbf{7 1}$ & $\mathbf{1 3}$ \\
\hline
\end{tabular}

\begin{tabular}{|c|c|c|c|c|c|c|c|}
\hline North East sector & 37.7526 & 14.9935 & May-Oct & 90 & 18 & 79 & 16 \\
\hline North East sector & 37.7530 & 14.9940 & May-Oct & 121 & 23 & 80 & 16 \\
\hline \multirow{2}{*}{ North East sector } & \multirow{2}{*}{37.7532} & \multirow{2}{*}{14.9949} & May-Jul & 56 & 17 & 37 & 14 \\
\hline & & & Jul-Oct & 115 & 23 & 57 & 13 \\
\hline \multirow{2}{*}{ North East sector } & \multirow{2}{*}{37.7529} & \multirow{2}{*}{14.9955} & May-Jul & 52 & 17 & udl & \\
\hline & & & Jul-Oct & 480 & 82 & 34 & 10 \\
\hline North East sector & 37.7526 & 14.9958 & May-Jul & lost & & 81 & 20 \\
\hline North East sector & 37.7522 & 14.9962 & May-Oct & 171 & 31 & 87 & 17 \\
\hline North East sector & 37.7518 & 14.9966 & May-Oct & 120 & 22 & 90 & 17 \\
\hline North East sector & 37.7511 & 14.9963 & May-Oct & 189 & 36 & 131 & 27 \\
\hline \multicolumn{4}{|l|}{ NE sector mean } & 155 & 43 & 75 & 10 \\
\hline Voragine vent hotspot & 37.7514 & 14.9965 & May-Oct & 26737 & 4327 & 8827 & 1430 \\
\hline \multicolumn{8}{|c|}{ South East sector } \\
\hline South East sector & 37.7504 & 14.9960 & May-Oct & 190 & 34 & 2593 & 422 \\
\hline South East sector & 37.7501 & 11.9960 & May-Oct & damaged & & damaged & \\
\hline \multirow{2}{*}{ South East sector } & \multirow{2}{*}{37.7496} & \multirow{2}{*}{14.9957} & May-Jul & 127 & 29 & 73 & 20 \\
\hline & & & Jul-Oct & 82 & 18 & 1091 & 180 \\
\hline South East sector & 37.7494 & 14.9954 & May-Oct & 313 & 53 & 80 & 16 \\
\hline South East sector & 37.7490 & 14.9948 & May-Oct & 248 & 43 & 163 & 29 \\
\hline South East sector & 37.7488 & 14.9943 & May-Oct & lost & & 222 & 39 \\
\hline South East sector & 37.7487 & 14.9938 & May-Oct & 847 & 140 & lost & \\
\hline \multicolumn{4}{|l|}{ SE sector mean } & 301 & 114 & 704 & 409 \\
\hline \multicolumn{8}{|c|}{ South West sector } \\
\hline South West sector & 37.7487 & 14.9933 & May-Oct & damaged & & 141 & 26 \\
\hline South West sector & 37.7490 & 14.9930 & May-Oct & 454 & 76 & 122 & 23 \\
\hline \multirow{2}{*}{ South West sector } & \multirow{2}{*}{37.7494} & \multirow{2}{*}{14.9926} & May-Jul & 73 & 20 & 62 & 18 \\
\hline & & & Jul-Oct & 37 & 10 & 156 & 29 \\
\hline South West sector & 37.7497 & 14.9923 & May-Oct & 204 & 36 & 69 & 14 \\
\hline South West sector & 37.7500 & 14.9920 & May-Oct & 362 & 51 & 50 & 11 \\
\hline South West sector & 37.7502 & 14.9914 & May-Oct & 123 & 23 & 65 & 13 \\
\hline South West sector & 37.7504 & 14.9909 & May-Oct & 51 & 11 & 52 & 11 \\
\hline SW sector mean & & & & 186 & 62 & 90 & 15 \\
\hline
\end{tabular}


Figure 1. 


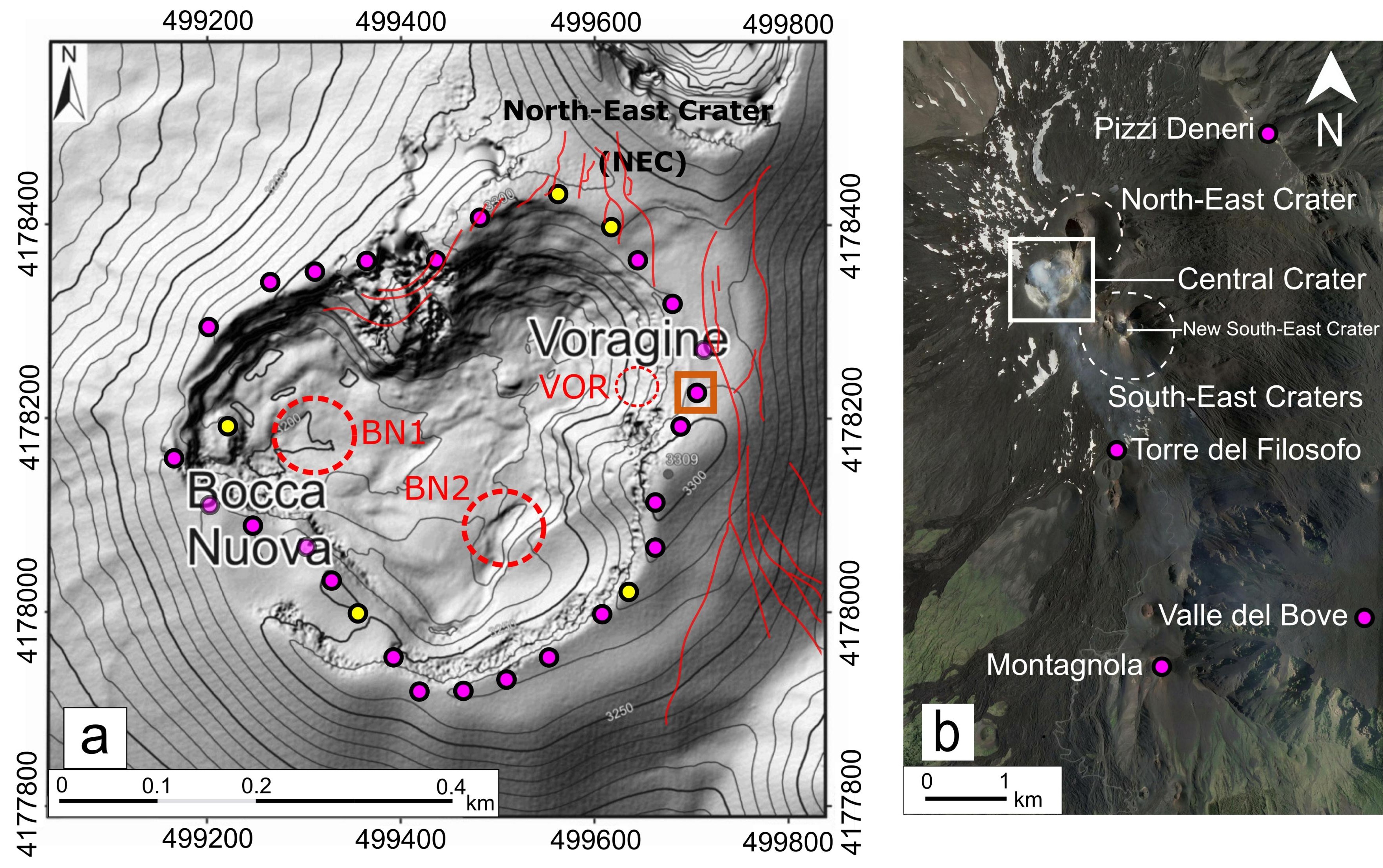


Figure 2. 
Figure 3. 


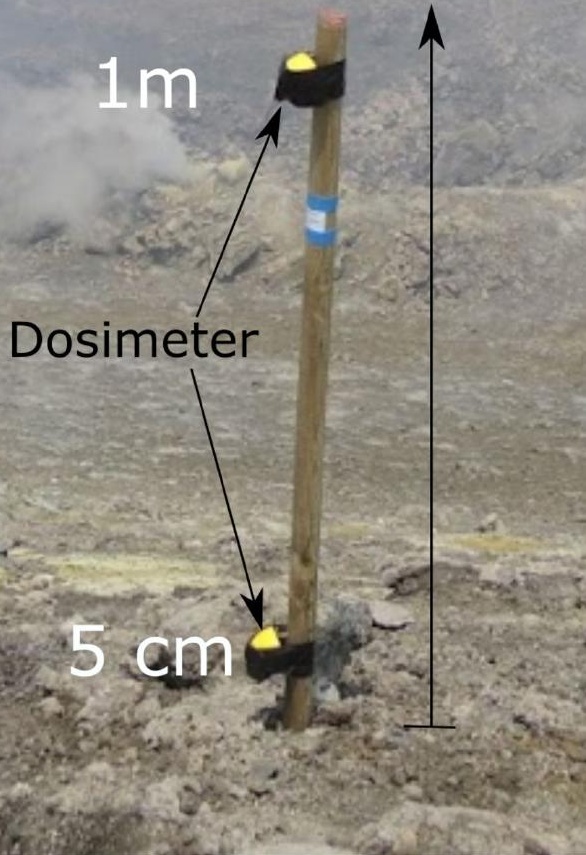


Figure 4. 

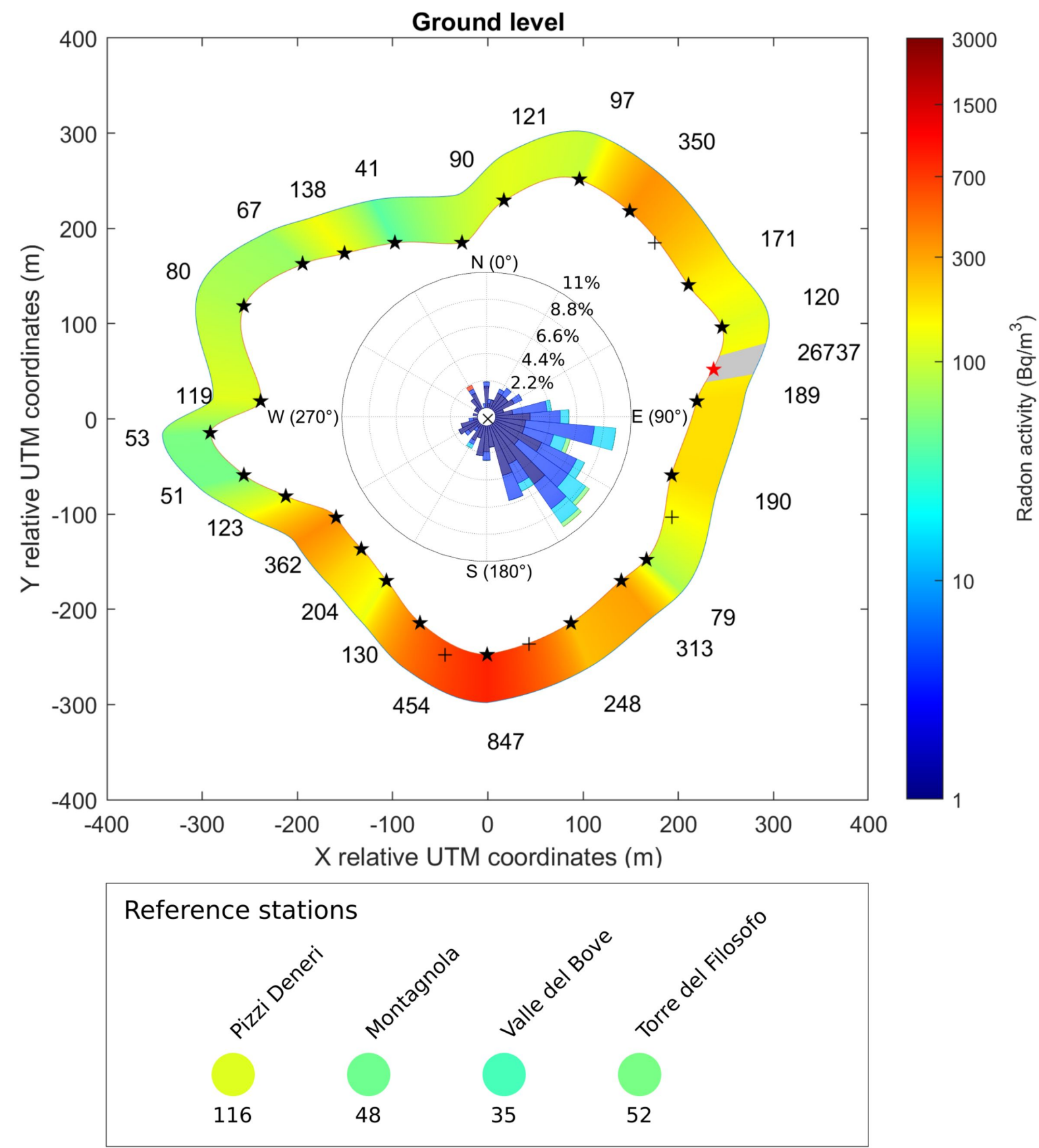

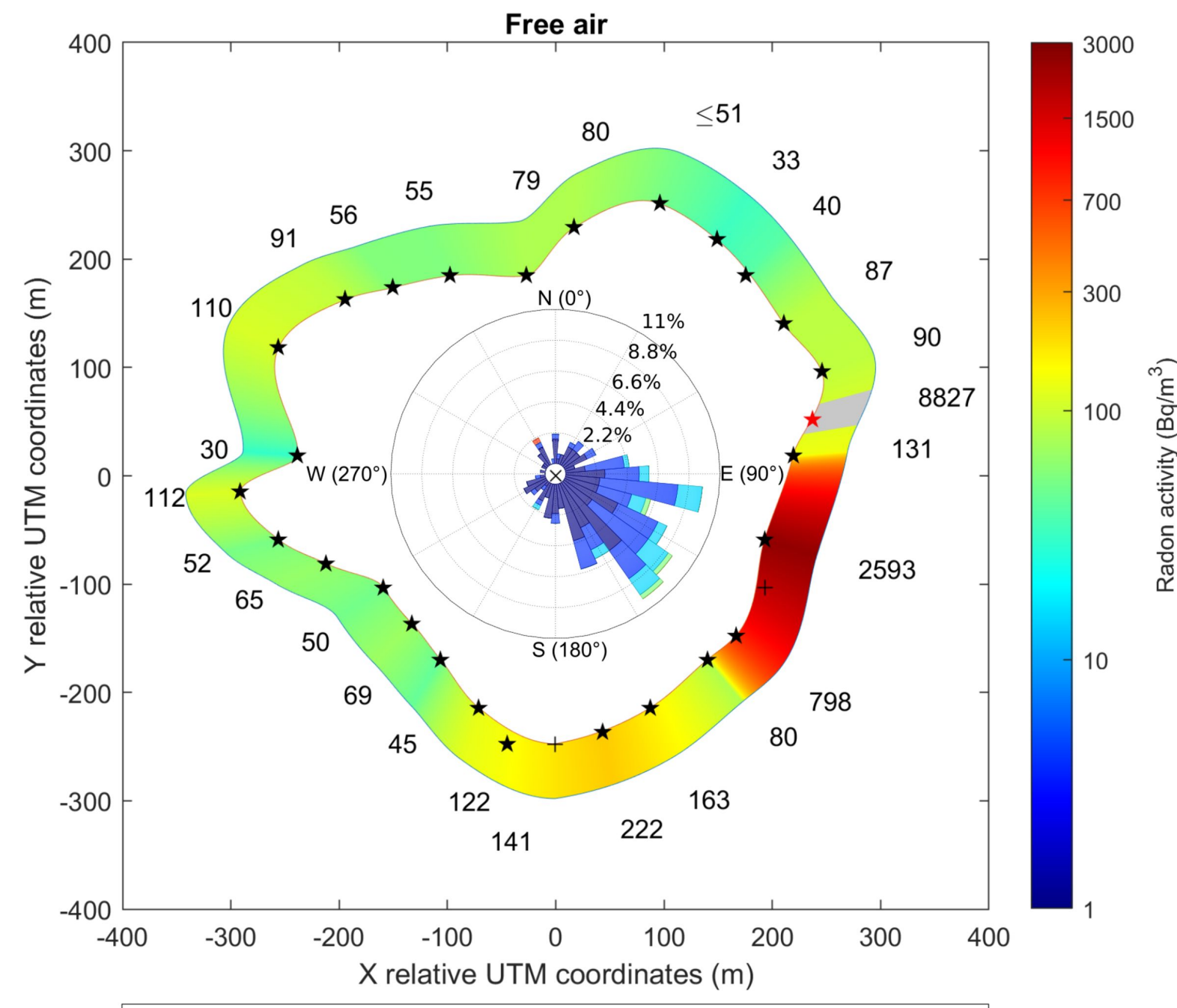

Wind Speeds in $\mathrm{m} / \mathrm{s}$
$\mathrm{W}_{\mathrm{S}} \geq 60$
$50 \leq \mathrm{W}_{\mathrm{S}}<60$
$40 \leq \mathrm{W}_{\mathrm{S}}<50$
$30 \leq \mathrm{W}_{\mathrm{S}}<40$
$20 \leq \mathrm{W}_{\mathrm{S}}<30$
$10 \leq \mathrm{W}_{\mathrm{S}}<20$
$\square \leq \mathrm{W}_{\mathrm{S}}<10$
$\square$

$\star$ Dosimetry stations with values

$\star$ Voragine hotspot

+ Dosimetry stations without values

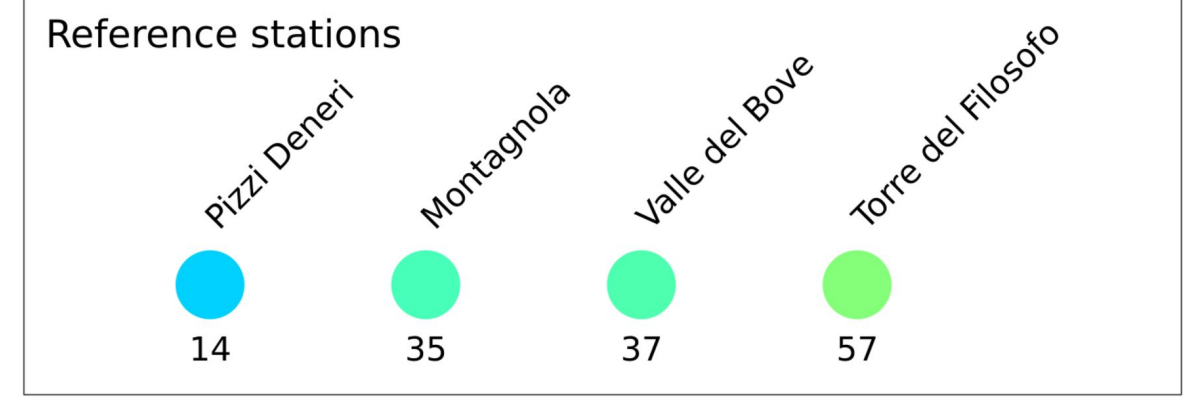


Figure 5. 
(a) NW

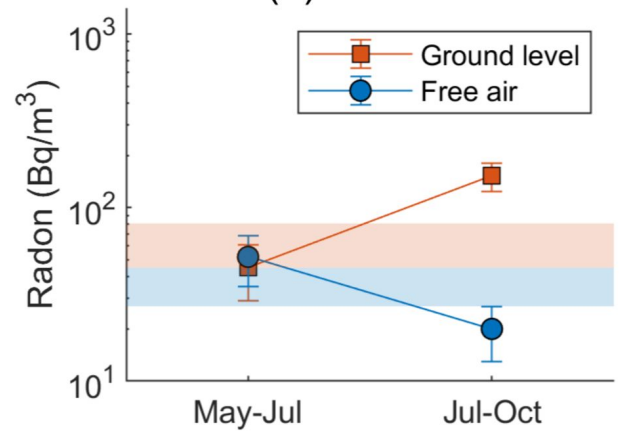

(c) SE

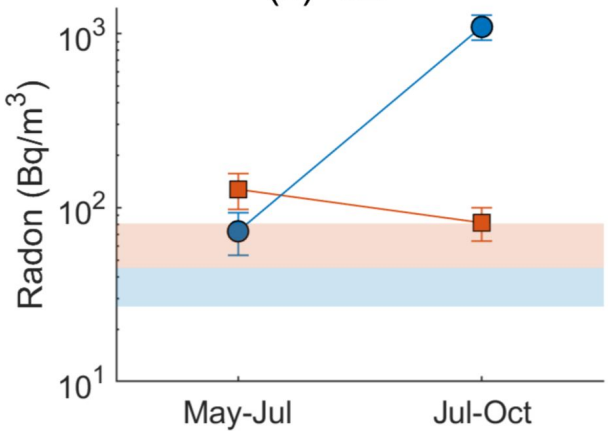

(e)

\section{Wind Speeds in $\mathrm{m} / \mathrm{s}$}

$W_{s} \geq 60$

$50 \leq W_{\mathrm{S}}<60$

$40 \leq W_{\mathrm{s}}<50$

$30 \leq W_{\mathrm{S}}<40$

$20 \leq \mathrm{W}_{\mathrm{s}}<30$

$10 \leq W / S<20$

$0 \leq W_{S}<10$

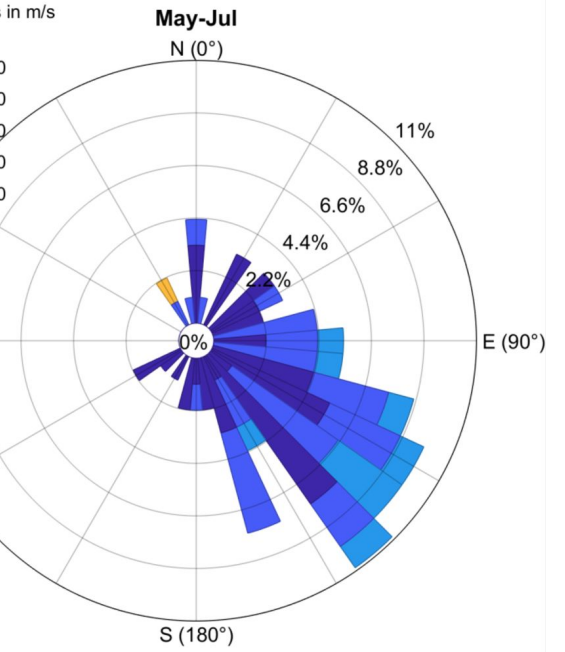

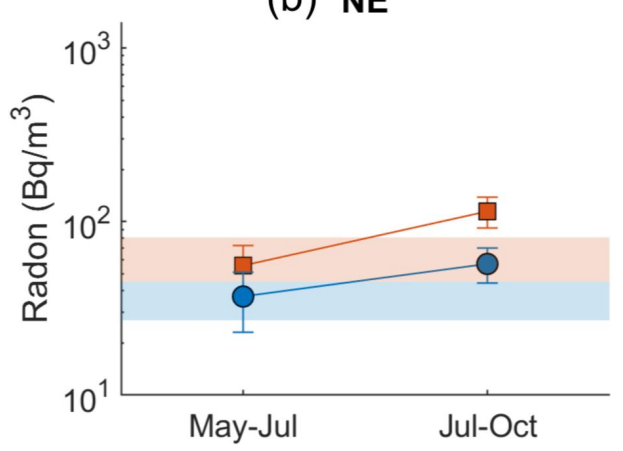

(d) sw

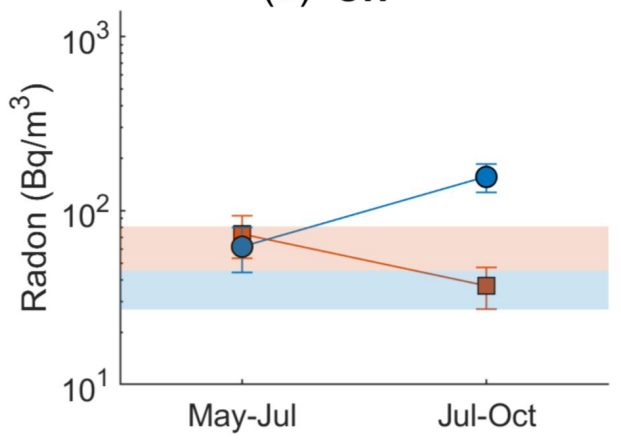

(f)

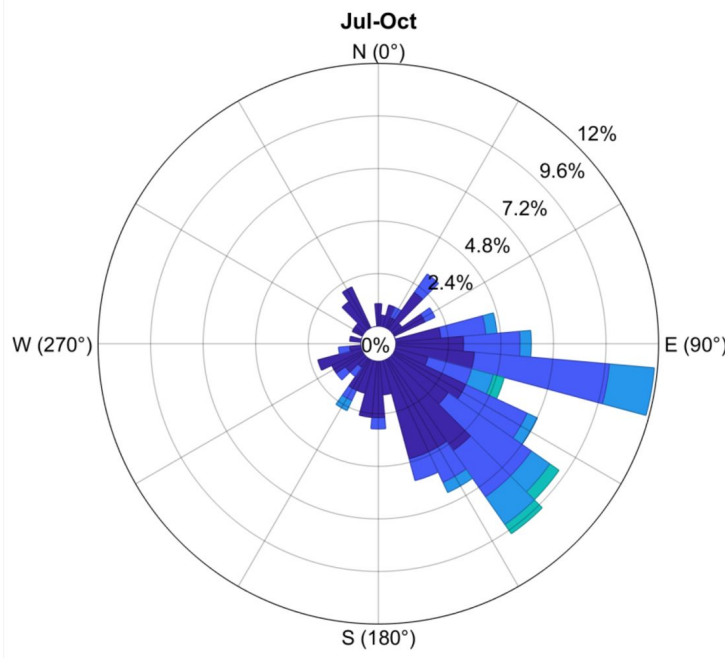

